Int. J. Plant Sci. 177(9):771-791. 2016.

(C) 2016 by The University of Chicago. All rights reserved.

1058-5893/2016/17709-0005\$15.00 DOI: 10.1086/688708

\title{
WESTERSHEIMIA PRAMELREUTHENSIS FROM THE CARNIAN (UPPER TRIASSIC) OF LUNZ, AUSTRIA: MORE EVIDENCE FOR A UNITEGMIC SEED COAT IN EARLY BENNETTITALES
}

\author{
Christian $\operatorname{Pott}^{1, *}$ \\ *Department of Palaeobiology, Swedish Museum of Natural History, Box 50007, SE-10405 Stockholm, Sweden
}

Editor: Patrick S. Herendeen

\begin{abstract}
Premise of research. Isolated ovules and dispersed seeds have been obtained from bulk macerations of carbonaceous shales bearing fossil plants from the Carnian (Upper Triassic) flora of Lunz am See, Austria. Through cuticle analysis, these well-preserved specimens were identified as ovules, interseminal scales, and seeds of Westersheimia pramelreuthensis, a peculiar bennettitalean ovuliferous organ. The preservation of several cuticular layers enables for interpretation of the architecture of the ovules and seeds.

Methodology. The excellently preserved plant fossils were investigated using LM and epifluorescence microscopy of cuticles. For comparison, the architecture of ovules and seeds of bennettitalean reproductive organs from Scania (Sweden), Jameson Land (Greenland), and Yorkshire (United Kingdom) were reevaluated.

Pivotal results. The preserved layers indicate that the nucellus is surrounded by an integument, whose apical end constitutes the micropyle. The single integument constitutes the monolayered seed coat in Westersheimia. The ovules and seeds are surrounded by interseminal scales. Of the latter, the cuticle is preserved that abuts the ovule-seed surface, together with portions of the interseminal scale heads. The seeds provide additional information on the cuticles of the nucellus or embryo.

Conclusions. Studies of bennettitalean reproductive organs from Scania (Sweden), Jameson Land (Greenland), and Yorkshire (United Kingdom) facilitated reevaluation of the disputed architecture of bennettitalean seeds. The findings clearly indicate that early bennettitalean seeds can be interpreted as unitegmic.
\end{abstract}

Keywords: micropylar plate, cupule, integument, seed anatomy, Bennettitales, Pterophyllum.

\section{Introduction}

The Carnian (Upper Triassic) flora of Lunz am See in Austria is well known for its abundant, diverse, and excellently preserved plant fossils (Pott 2007), among which the bennettites have drawn most attention (e.g., Krasser 1917, 1919a; Kräusel 1948, 1949; Pott et al. 2007c, 2007d, 2010a). During the last decade, research focused on revising the plant remains of this important flora revealed the presence of sphenophytes, ferns, Nilssoniales, cycads, bennettites, and conifers (Pott 2007; Pott et al. 2008a; Pott and Krings 2010). Among the most dominant plant groups in the Lunz flora are the Bennettitales, an extinct lineage of Mesozoic seed plants with cycad-like foliage and flowerlike reproductive structures (Pott et al. 2007c, 2007d, $2010 a$ ). The group has received particular attention as a possible sister group to the angiosperms (e.g., Friis et al. 2007, 2011), and in some phylogenetic analyses it is nested with the Gnetales and angiosperms in the so-called anthophyte clade (Arber and Parkin 1907; Crane 1985; Doyle and Donoghue 1986; Hil-

\footnotetext{
${ }^{1}$ E-mail: christian.pott@nrm.se.
}

Manuscript received March 2016; revised manuscript received May 2016; electronically published October 12, 2016. ton and Bateman 2006; Friis et al. 2007), whereas in other analyses, Gnetales are nested with conifers (e.g., Doyle 2006, 2008, 2012). The anthophyte concept is consequently not universally accepted, and currently there is no consensus regarding the interrelationships among seed plants (Doyle 2006, 2008, 2012).

One controversial feature in Bennettitales is the presence or absence of an outer layer enveloping the seed (see Doyle 2006, 2012; Friis et al. 2011 for review). Different concepts as to its presence or absence and possible homologies have been debated in the past. The structure has been referred to as a cupule and has been regarded as homologous with the cupule of Mesozoic seed ferns or the outer integument of the angiosperms (e.g., Harris 1932, 1954; Crane 1985; Pedersen et al. 1989; but see Doyle 2008, 2012 for review) or with the outer envelope in Gnetales (seed envelope; e.g., Friis et al. 2009, 2011). However, the debate is complex and cannot be investigated comprehensively in this article (see Rothwell and Stockey 2002; Doyle 2006, 2008, 2012; Friis et al. 2009, 2011).

This article presents new information on the genus Westersheimia Krasser, a poorly understood Late Triassic member of the Mesozoic seed plant order Bennettitales. Westersheimia pramelreuthensis Krasser is a peculiar bennettitalean reproductive structure from the Carnian flora of Lunz. Westersheimia is often cited because it is one of the oldest known bennettites 
and appears to have pinnate ovulate structures. Phylogenetic analyses that have included Westersheimia place it as sister to the rest of the Bennettitales (Crane 1988; Crepet and Stevenson 2010). Based on new material (i.e., isolated ovules and interseminal scales and dispersed seeds) deriving from bulk macerations and identified through cuticle analysis, detailed new micromorphological data are presented in combination with a thorough examination of the original material.

In this article, I also present new observations on other Upper Triassic bennettites (Wielandiella Nath., Vardekloeftia T.M.Harris), showing that the ringlike plate around the micropyle (the so-called micropylar plate) is part of the ovule or seed rather than a distinct organ. These results provide vital information on the architecture of ovules and seeds in early Bennettitales and may help to explore the question of the presence of a second layer around the seeds (cupule or bitegmic architecture) of these plants, which has entered into discussions of possible homologies with glossopterids, Caytonia T.M.Harris, Gnetales, and angiosperms (e.g., see Doyle 2008, 2012).

The Triassic record of bennettitalean reproductive structures primarily consists of isolated parts of reproductive organs and fragmentary compound organs, some of which are only poorly understood (e.g., Krasser 1917, 1919a, 1919b; Harris 1932; Kräusel 1948, 1949; Kräusel and Schaarschmidt 1966; Ash 1968; Pedersen et al. 1989; Anderson and Anderson 2003; Anderson et al. 2007; Pott et al. 2010a; Pott 2014a; Pott and Axsmith 2015). The Bennettitales from the Carnian of Lunz are among the oldest representatives of the group (Anderson et al. 2007; Pott et al. 2008a, 2010b) and are therefore of particular interest in determining the architecture and functionality of early bennettitalean reproductive organs. They also play an important role in analyses of the relationships of major groups of seed plants (e.g., Crane 1985, 1986, 1988; Crepet and Stevenson 2010; Friis et al. 2011), with particular influence and potential for resolving some of the relationships among gymnosperms and angiosperms.

Westersheimia pramelreuthensis has variously been interpreted as an ovuliferous organ or a microsporophyll (Krasser 1917; Langer 1943; Kräusel 1949; Crane 1986, 1988; Taylor et al. 2009; Crepet and Stevenson 2010; Friis et al. 2011) and became renowned because the holotype specimen shows one of these organs apparently attached to a prominent stem with scars of abscised leaves, accompanied by well-preserved Pterophyllum Brongn. foliage. Krasser (1917, p. 549) regarded this fertile organ as macrosporophyll but did not give any justification or further interpretation: "The macrosporophyll is a segmented leaf, with elongate, mulberry-like segments of the structure of a Williamsonia." Langer (1943, p. 55) recognized Westersheimia as one of the "most interesting fructifications of the cycadophytes" and followed Krasser's (1917) interpretation of a fertile organ organically attached to a very prominent stem, even if with Langer (1943, p. 55), the structure was named a microsporophyll, probably by mistake. Apart from the repetition of Krasser's (1917) statement, Langer (1943) refrained from giving any further description or interpretation of the organ.

The most comprehensive examination and interpretation of W. pramelreuthensis (as an ovuliferous organ) were conducted by Kräusel (1949); the author was also able to isolate small pieces of cuticle that allowed the allocation of the additional material presented here to W. pramelreuthensis. Later studies by, for example, Crane $(1985,1986,1988)$ and Crepet and Stevenson (2010) adopted the concept of Westersheimia presented by Krasser (1917) and Kräusel (1949; ovuliferous organ with laterally attached gynoecia and attached to a prominent stem). Crane (1985, p. 740) noted the "unusual morphology" of Westersheimia; later, Crane (1986, p. 167) commented that Westersheimia still presented a "major outstanding problem" in the interpretation of many bennettitalean ovules. Crepet and Stevenson's (2010) scoring of the ovulate structure of Westersheimia as "pinnate" or "unknown" placed it at the base of the Bennettitales or the relationships of Bennettitales were unresolved, respectively. The detailed study of $W$. pramelreuthensis presented here is consequently conducted with great care to help resolve its relationships with other bennettitaleans.

\section{Material, Methods, and Geological Setting}

\section{Material and Geological Setting}

All available original macrofossil material for the studies of Krasser (1917) and Kräusel (1949) from the Lunz flora was considered here. The 10 specimens were rigorously examined in profound detail using a dissecting microscope and advanced digital photography. The cuticular specimens analyzed here were obtained during maceration of rock samples or were found in the residue of fossiliferous blocks that were macerated for different purposes in earlier studies of the Lunz flora (e.g., Pott et al. 2007a, 2007b, 2010a). Some of the specimens were obtained from bulk macerations of whole blocks. Therefore, no compression fossils are available that could be linked with these cuticles. All studied samples were collected from several former coal mines around Lunz am See in the Northern Calcareous Alps of Austria, approximately $100 \mathrm{~km}$ west of Vienna (fig. 1), during the late nineteenth and early twentieth centuries. The precise source (namely, coal mine) of each sample cannot be determined.

The fossils derive from the so-called Lunzer Sandstein that is part of the Lunz Formation (= Lunzer Schichten). This unit consists of basal sandstones that are overlain by marine marls grading upward into terrestrial sands, shales, and coal. The coal-bearing part is topped by marls that are again overlain by a sandstone layer. The plant fossils are found in the shales associated with the coal beds. Exact dating of the Lunz For-

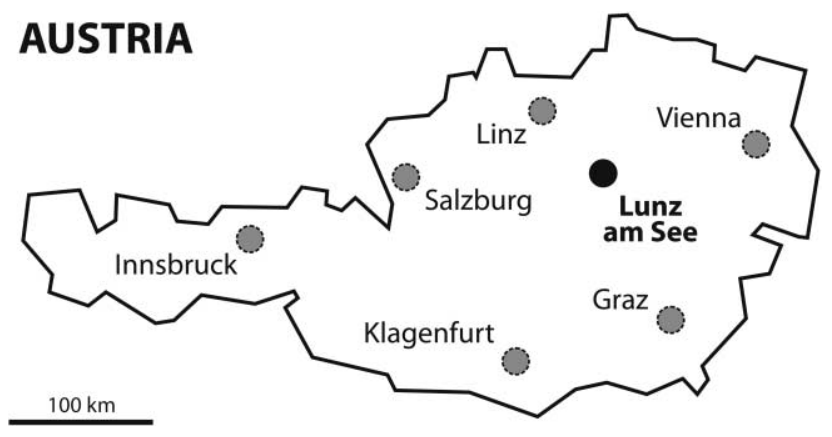

Fig. 1 Map depicting the position of Lunz am See in Austria. 
mation remains problematic owing to the lack of adequate index fossils. The Lunz Formation is suggested to correlate to the upper part of the Reingraben Formation on the basis of regional and facies-spanning correlation of biostratigraphically well-established sections of the Hallstatt and Reifling Intraplatform basins (Hornung and Brandner 2005). Consequently, it is most probably late Julian (Julian 2/II) in age, which is confirmed by palynological studies that indicate a Carnian (Bharadwaj and Singh 1964) and Julian (Dunay and Fisher 1978; Roghi 2004) age. The upper subunit of the Lunzer Schichten (Opponitzer Limestone) has been dated as Tuvalian by Dunay and Fisher (1978). Julian and Tuvalian are regional chronostratigraphic substages of the Carnian, which correlate to the middle and upper Carnian, respectively. For more information on the geological setting, refer to the work of Pott (2007) and Pott et al. (2008b, 2010a).

Specimens studied and figured in this article are held in the paleobotanical collections of the Museum of Natural History, Vienna, Austria (NHMW); the Geological Survey of Austria, Vienna (GBAW); and the Swedish Museum of Natural History, Stockholm (NRM). Specimen numbers are included in the figure legends.

\section{Methods}

Cuticle analysis. The plant fossils from Lunz are commonly preserved as compressions with excellently preserved cuticles. Cuticles were prepared according to the procedures as outlined by Kerp (1990), Pott and Kerp (2008), and Pott and McLoughlin (2009). Rock samples with plant remains were dissolved in hydrofluoric acid $(40 \%)$ for 4 or $5 \mathrm{~d}$ to remove the sediment. Isolated and cleaned cuticles were macerated using Schulze's reagent $\left(35 \% \mathrm{HNO}_{3}\right.$ with a few crystals of $\left.\mathrm{KClO}_{3}\right)$ for about $170 \mathrm{~h}$ and subsequently treated with a $5 \%-10 \%$ potassium hydroxide $(\mathrm{KOH})$ solution for a few seconds. Macerated cuticles were washed in distilled water, gently dehydrated in pure glycerine for $48 \mathrm{~h}$, and finally mounted on permanent glycerine jelly microscope slides. Slides produced during the study are stored in the collections of the respective institutes (see previous section).

Photography. Hand specimens were photographed with a Nikon D80/Nikkor AF-S Mikro 60-mm 1:2.8G ED system digital camera; to enhance contrast, cross-polarization (i.e., polarized light sources together with an analyzing filter in front of the camera lens) was used. Cuticles were analyzed with an Olympus BX-51 microscope that was modified for epifluorescence microscopy and were photographed with an Olympus DP-71 digital camera.

\section{Systematic Paleontology (Results)}

Order-Bennettitales Engl. 1892

Family - incertae familiae

Genus-Westersheimia Krasser 1917, emend. Kräusel 1949

Diagnosis. Pinnately segmented bennettitalean ovuliferous reproductive organs; lateral segments each consisting of one cone composed of numerous ovules and interseminal scales (translated from Kräusel 1949, p. 70, without modification or additions).

Type. Westersheimia pramelreuthensis Krasser 1917.
Species-Westersheimia pramelreuthensis Krasser 1917, here emend. C.Pott

Remark on the publication date. The names Westersheimia and Westersheimia pramelreuthensis were validly published as “Westersheimia pramelreuthensis g. et sp. n.” by Krasser (1917) in volume 94 of the Denkschriften, Kaiserliche Akademie der Wissenschaften Wien, Mathematisch-Naturwissenschaftliche Klasse (issued 1918). The two identical notes published in 1916 (reports from the December 14, 1916, session of the Austrian Royal Academy of Sciences; Krasser 1916a, p. 286; 1916b, p. 337) lack illustrations and thus cannot be regarded as valid publication of the names (article 43.2 of the International Code of Nomenclature; McNeill et al. 2012).

References. Westersheimia pramelreuthensis, Krasser 1916 a (p. 286; no illustration); W. pramelreuthensis, Krasser $1916 b$ (p. 337; no illustration); W. pramelreuthensis, Krasser 1917 (pp. 492, 549; fig. 1); W. pramelreuthensis, Langer 1943 (p. 55; no illustration); W. pramelreuthensis, Kräusel 1949 (p. 66; figs. 14-16; pl. 16, figs. 3-6; pl. 17, figs. 1-4; pl. 18, figs. 1-3); W. pramelreuthensis, Crane 1985 (p. 740; no illustration); W. pramelreuthensis, Crane 1986 (p. 167; fig. 11.3 [reproduction of Kräusel's concept and figure]); W. pramelreuthensis, Crane 1988 (p. 244; fig. 5.9; reprise of Crane 1986); W. pramelreuthensis, Taylor et al. 2009 (p. 739; fig. 17.94); W. pramelreuthensis, Crepet and Stevenson 2010 (p. 230; fig. 10.5 [reproduction of Kräusel's concept and figure]); W. pramelreuthensis, Friis et al. 2011 (p. 130; no illustration).

Emended diagnosis. Bennettitalean ovuliferous organ, pinnately segmented, with five to seven pairs of laterally inserted axes terminated by cone-like organs (gynoecia); gynoecia shortly stalked, central axis continuing into an elongate receptacle, carrying numerous orthotropous ovules interspersed with slender interseminal scales; heads of the latter forming a cone surface with intermittent openings where micropyles project beyond the surface layer; epidermal cells of the walls of the interseminal scales slender and elongate with delicate, slightly undulate anticlinal cell walls, becoming more heavy walled and smaller or polygonal toward the interseminal scale heads; interseminal scale heads with brachyparacytic stomata; ovules or unitegmic seeds with small polygonal cells on their integuments (modified from Kräusel 1949, p. 70).

Type. GBAW 1917/001/0020, here figured in figure $2 A$.

Additional macrofossil material. NHMW 1884/0500/1207, 1885/0500/3971, 1885/0500/4066, 1885/0500/4130; GBAW 1909/003/0851, 1917/001/0009, 1917/001/0023, 1917/001/0024; NRM S148227.

Cuticle material from the following macrofossil specimens. NHMW 1883/0100/5965 (slide 0003), 1885/0500/3893 (slide 0001), 1885/0500/3893 (slides 0002, 0003), 1885/0500/4026 (slides 0012, 0013), 1885/0500/4124 (slides 0003, 0006), 2006B0008/ 0010 (slides 0086, 0087, 0088, 0089); GBAW 1909/003/0149 (slide 0013).

Remarks on the specimens. The specimens figured and described in figures 6-9 represent cuticle portions of bennettitalean ovuliferous organs that have been obtained by maceration. Therefore, no compression fossils linked to these cuticles are available. All cuticle portions are interpreted to represent ovules after pollination during maturation into seeds or mature re- 

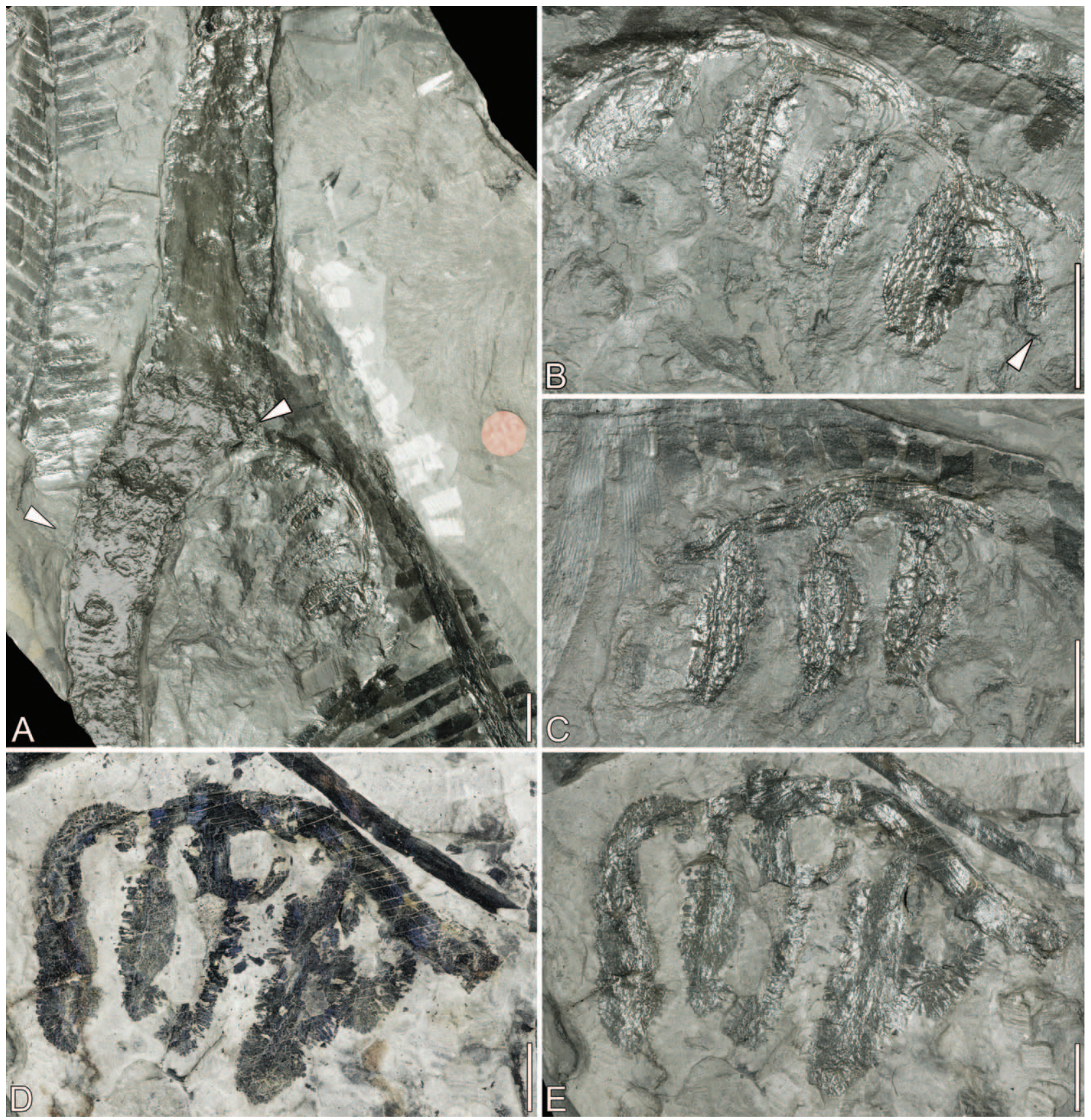

Fig. 2 Westersheimia pramelreuthensis Krasser, ovuliferous organ, from the Carnian of Lunz am See, Austria. A, Type specimen showing a Westersheimia organ (right arrowhead) beside a prominent stem with leaf scars (left arrowhead), presumably of a plant producing sterile Pterophyllum filicoides foliage, one leaf of which is visible to the upper left of the specimen. The Westersheimia organ is not organically linked with the stem, but the coating of the specimen with varnish suggests this (see main text for more information). The lowermost segment (gynoecium) of the Westersheimia organ (arrowhead) led Kräusel (1949) to argue for an imparipinnate organization of the organ. GBAW 1917/001/ 0020. B, Detail of the type specimen showing the Westersheimia organ only. C, Counterpart of the type specimen. GBAW 1917/001/0023. D, E, Well-preserved Westersheimia organ with five pairs of gynoecia; note the prominent central axis. Specimens were photographed with different filters in front of lamps and the camera lens to enhance different details. GBAW 1917/001/0024. Scale bars: $1 \mathrm{~cm}$.

leased seeds. Ten isolated ovules and five dispersed seeds have been found. The conspecificity with material assigned to W.pramelreuthensis is justified by identical cuticle portions obtained in situ by Kräusel (1949, pl. 18, figs. 1-3) from specimens yield- ing W. pramelreuthensis (specimens B5876-B5878, stored in Senckenberg Natural History Museum, Frankfurt, Germany).

One specimen included here (namely, S148227; fig. 3A) had earlier been misidentified as Bernoullia lunzensis Stur (=Symop- 

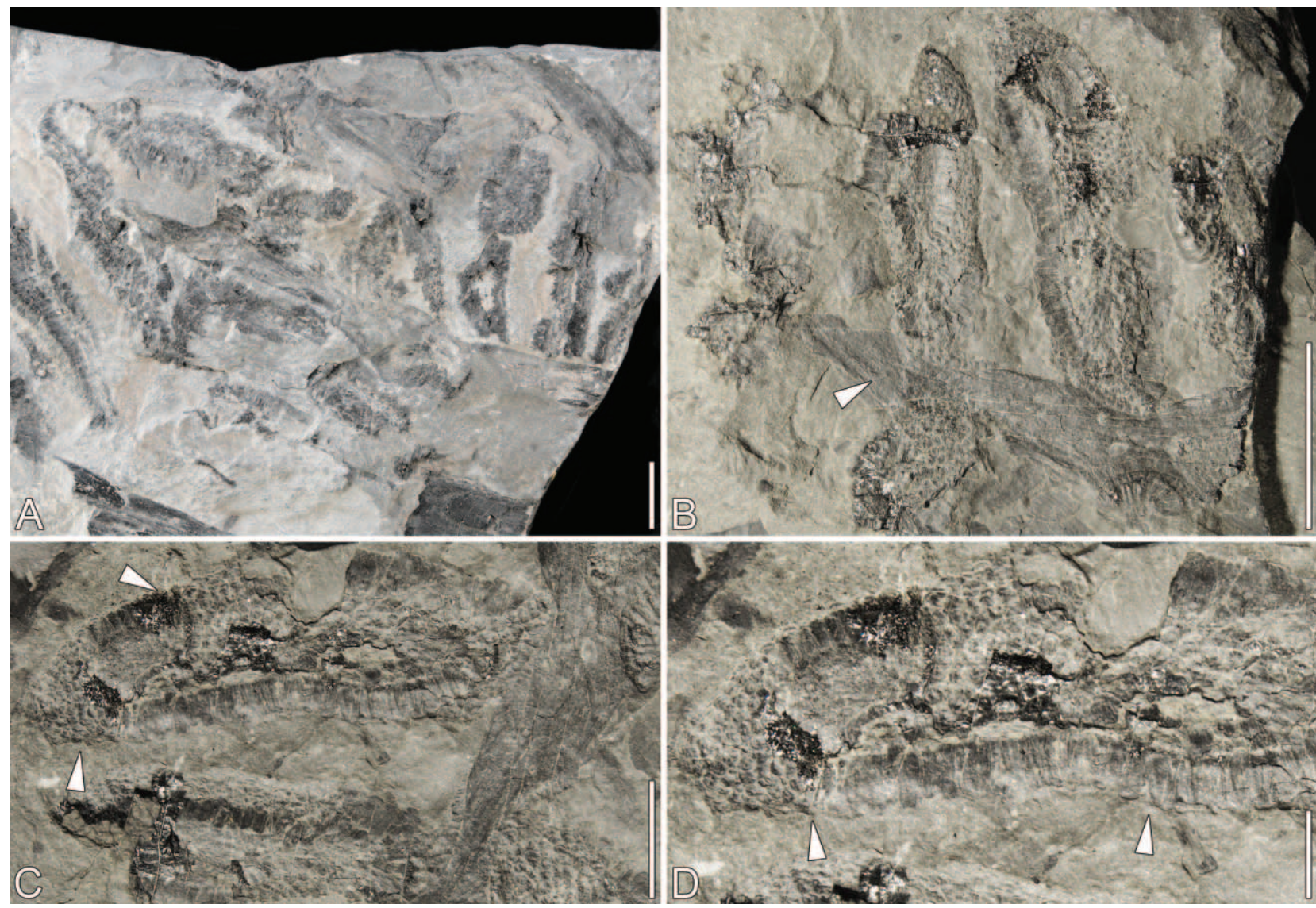

Fig. 3 Westersheimia pramelreuthensis Krasser, ovuliferous organ, from the Carnian of Lunz am See, Austria. A, NRM S148227, earlier misidentified as Bernoullia lunzensis but showing well-preserved Westersheimia gynoecia. B, Well-preserved Westersheimia organ with four pairs of gynoecia; note the prominent central axis and the pinnate arrangement of the gynoecia (arrowhead). $C$, Detail of specimen in $B$; note the gynoecia covered on all sides, even the tip, with interspersed ovules and interseminal scales (arrowheads). $D$, Close-up of $C$ showing the layer of ovules and interseminal scales in surface view and cross section (arrowheads). NHMW 1884/0500/1207, photographed with different filters in front of lamps and the camera lens to enhance different details. Scale bars: $A, B=1 \mathrm{~cm} ; C=5 \mathrm{~mm} ; D=2.5 \mathrm{~mm}$.

teris lunzensis [Stur] R.Xu, J.N.Zhu, Ye.Chen, S.Y.Duan, Yu.F.Hu et W.Q.Zhu) by collectors or collection personnel but had already been identified as W. pramelreuthensis by Pott in Kustatscher et al. (2011). One of the seeds presented here (fig. 9A) was earlier considered a seed of Bennetticarpus wettsteinii (Krasser) Kräusel by Pott et al. (2010a) because the seed came from a slab yielding a B. wettsteinii cone. However, the seed is much too small $(1.5 \mathrm{~mm} \times 1.8 \mathrm{~mm})$ compared to in situ seeds of B. wettsteinii ( 13-14 mm long; Pott et al. 2010a), and it is therefore unlikely that it is a seed of B. wettsteinii. The earlier interpretation must be revised here, and it is better regarded as a seed of W. pramelreuthensis instead, based on several interseminal scales obtained from the same small sample that are clearly attributable to the latter.

Type locality. Lunz, Lower Austria, Austria.

Type unit and age. Lunz Formation, Carnian (Julian, $\approx 230 \mathrm{Ma}$ ).

Distribution. Triassic, Carnian: Austria.

Description. Westersheimia pramelreuthensis comprises pinnate reproductive organs or megasporophylls (figs. 2,3). Whether the organs were pari- or imparipinnate is difficult to ascertain; Kräusel (1949) argued for an imparipinnate architecture based on his interpretation of the type specimen (fig. 2A). Ten macrofossil specimens are available that yield more or less complete organs or individual segments (cone-like gynoecia). The whole W. pramelreuthensis reproductive organ is up to $78 \mathrm{~mm}$ long (figs. $2 A-2 E, 3 B$ ). A central robust axis, up to $6 \mathrm{~mm}$ wide, gives off five to seven pairs of oppositely arranged axes carrying the gynoecia (ovuliferous organs; figs. $2 B, 2 D, 2 E, 3 A-3 C$ ); there is no indication that they were spirally arranged (fig. $3 B$ ). The ovuliferous organs are oblong or narrowly elliptic to oval in gross outline, $15-40 \mathrm{~mm}$ long, and $9-15 \mathrm{~mm}$ wide (figs. 3C, $3 D, 4 A-4 D$ ). Their stalks are $2-3 \mathrm{~mm}$ wide but only $1-2 \mathrm{~mm}$ long proximal to the layer of scales (fig. 4G). Each gynoecium consists of a central elongate receptacle, which is as wide as the stalk and entirely covered on all sides with densely arranged, tiny, oblong to ovate orthotropous ovules (or seeds) interspersed with interseminal scales (fig. $4 A-4 F, 4 H, 4 J$ ). The scales are $1.5-3.0 \mathrm{~mm}$ long and about $1 \mathrm{~mm}$ wide. The surface of the scales bears longitudinal striae; an embossed margin or bulge is present in some scales (fig. 4H), identifying these most probably as seeds.

The receptacle has comparatively heavy cutinization (fig. $5 \mathrm{~A}$ ); its epidermis consists of very slender, elongate cells, 74-88 $\mu \mathrm{m}$ 

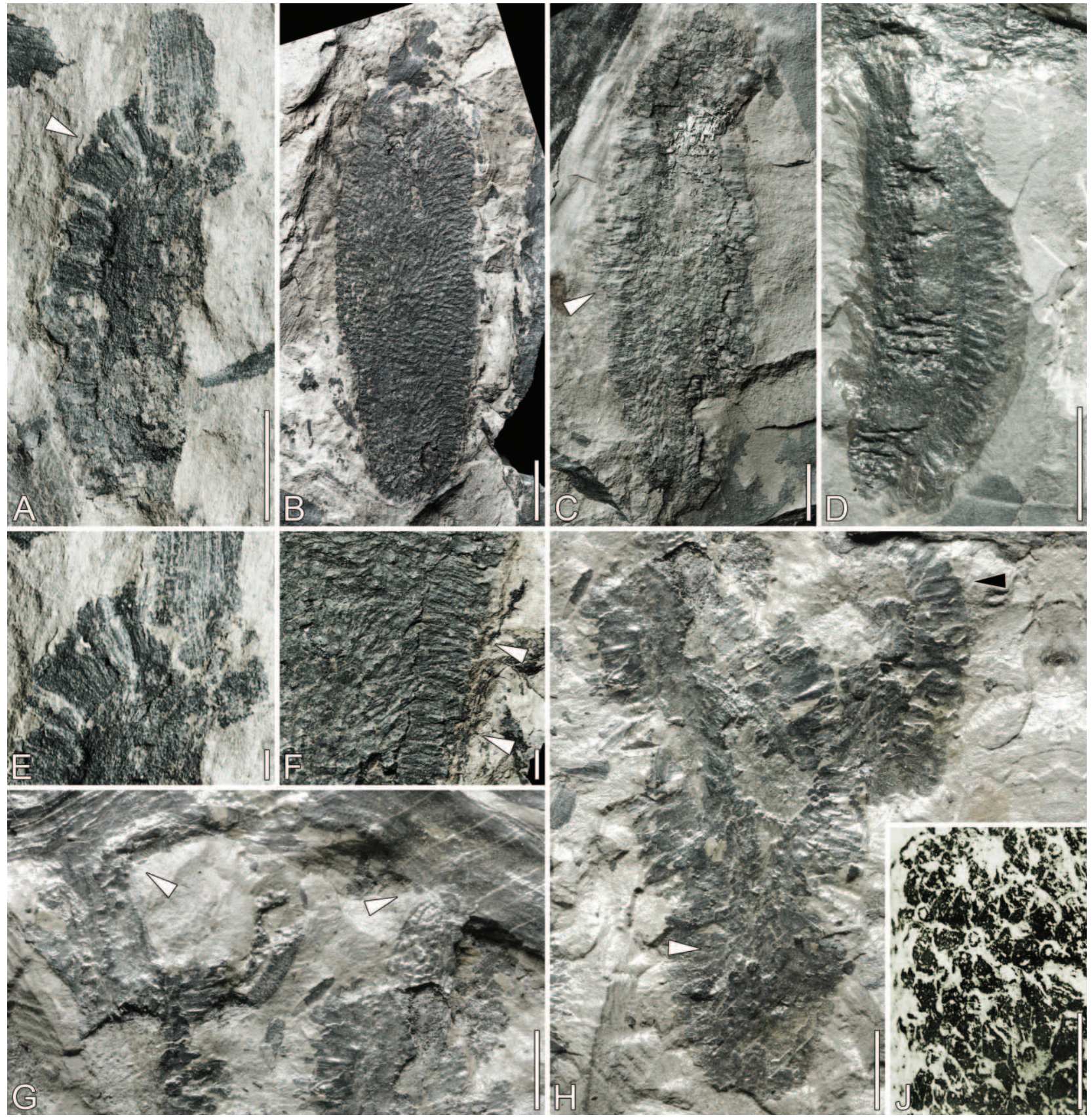

Fig. 4 Gynoecia of Westersheimia pramelreuthensis Krasser. A, Individual gynoecium with short petiole and the layer of ovuliferous and interseminal scales visible on the left side (arrowhead) of the receptacle. NHMW 1885/0500/3971. B, Isolated gynoecium completely covered with ovuliferous and interseminal scales, some of which are distorted by taphonomical processes. NHMW 1885/0500/4130. C, Individual gynoecium with well-preserved ovuliferous and interseminal scales (arrowhead). NHMW 1885/0500/4066. D, Individual gynoecium with well-preserved ovuliferous and interseminal scales. GBAW 1909/003/0851. E, Detail of $A$ showing details of the mantle of ovuliferous and interseminal scales. $F$, Detail of $B$, visualizing the mantle of ovuliferous and interseminal scales. $G$, Detail of figure $2 D, 2 E$ showing the attachment of the cones to the central axis of the organ (arrowheads). H, J, Detail of figure 2D, 2E, enhancing the area (white arrowhead) where Kräusel (1949) illustrated the outer surface of the cone $(J)$, and ovuliferous scales with prominent marginal bulge (black arrowhead). $J$, Reproduction of Kräusel (1949, pl. 17, fig. 4). Reproduction with permission from Schweitzerbart, Stuttgart, Germany. Scale bars: $A-D, G, H=5 \mathrm{~mm} ; E, F, J=1 \mathrm{~mm}$.

long and $16-22 \mu \mathrm{m}$ wide, commonly characterized by skewed polar walls. The periclinal cell walls appear to be even more heavily cutinized than the anticlinal cell walls. The stalks of the ovuliferous and interseminal scales are 500-580 $\mu \mathrm{m}$ wide and are inserted perpendicular to the receptacle; they have a contiguous arrangement. Epidermal cells of the stalks are commonly polygonal (31-44 $\mu \mathrm{m}$ across) toward the base of the stalks but become progressively more elongate acropetally. In the center 

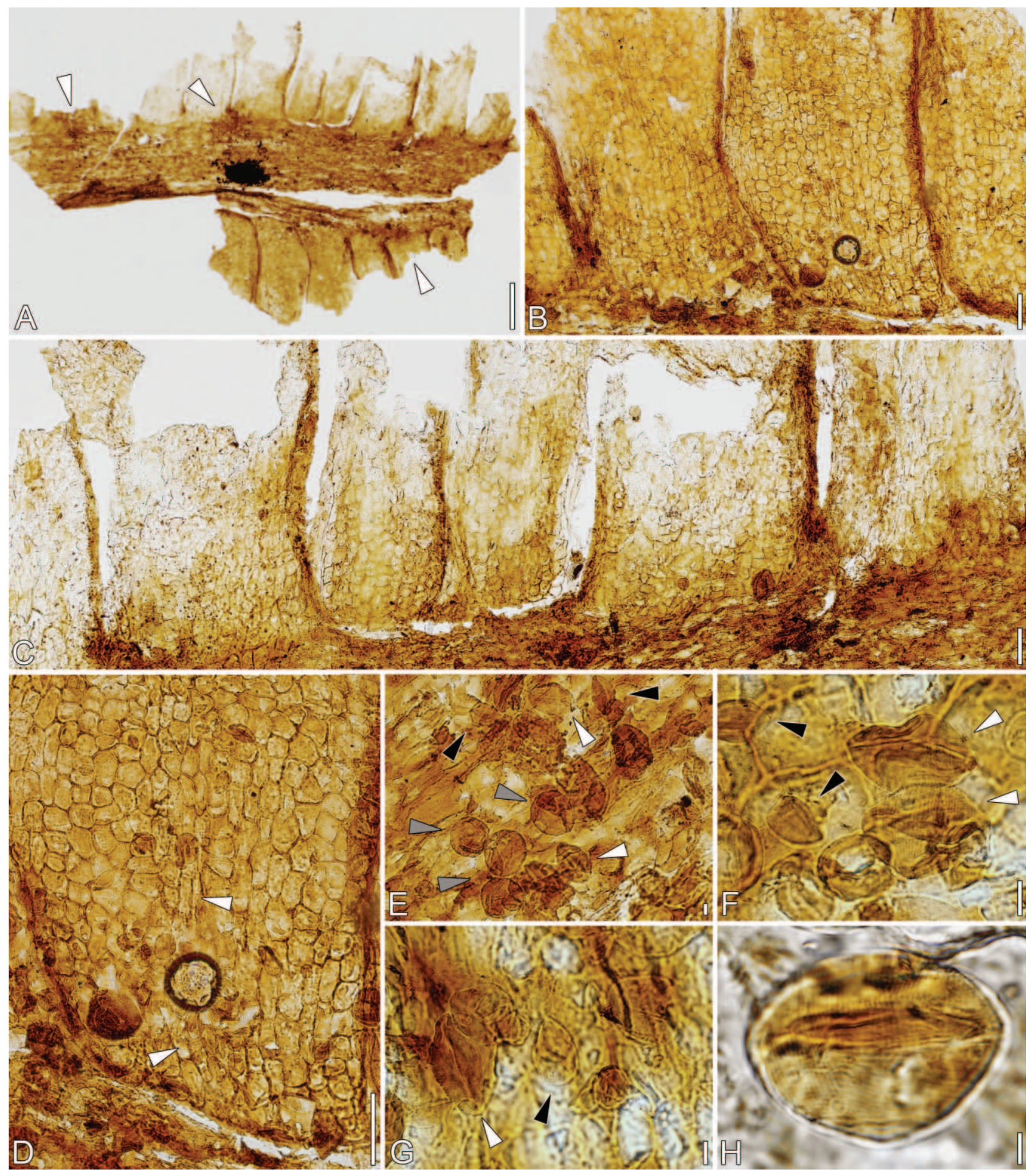

Fig. 5 Receptacle with attached stalks of ovuliferous and interseminal scales of Westersheimia pramelreuthensis Krasser. Cuticle slide made from GBAW 1909/003/0851 (see fig. 4D), slide 0001. A, Overview of the preserved portion; arrowheads indicate areas with larger aggregation of pollen grains. $B$, Detail of the stalk bases in the lower portion in $A$; note the close arrangement of the stalks. $C$, Detail of the stalk bases in the upper portion in $A$; note the close arrangement of the stalks and pollen grain accumulations. $D$, Detail of one stalk base; note the elongate cells reflecting the supporting vascular bundle (arrowheads). E-G, Aggregation of different types of spores and pollen grains at the bases and between the stalks. Note the three different major types: presumed spores of Asterotheca merianii (gray arrowheads), pollen identified as Decussatisporites delineatus (white arrowheads), and pollen identified with in situ pollen of Lunzia austriaca (black arrowheads). H, Decussatisporites delineatus pollen in detail; note the striate exine. Scale bars: $A=500 \mu \mathrm{m}, B-D=100 \mu \mathrm{m}, E-H=10 \mu \mathrm{m}$. 
of the stalk, one or two lines of slender and elongate epidermal cells are visible that might reflect a vascular bundle passing longitudinally through the stalk to the ovule or interseminal scale. Stomata have not been observed on the receptacle or the stalks. All stalks visible in figure $5 A-5 D$ are of the same appearance, supporting the assumption of the homology of interseminal and ovuliferous scales (see below).

The macerated ovules are oblong to ovate in lateral outline, 2.8-3.4 $\mathrm{mm}$ long, and up to $1.5 \mathrm{~mm}$ wide, tapering to their distal (micropylar) end and obtusely rounded at their proximal (chalazal) end (fig. 6). The ovules have a short micropyle at the apex (figs. $6 F, 7 A-7 C$ ) and a round hole at the base (figs. $6 B-$ $6 \mathrm{D}, 6 \mathrm{G}, 6 \mathrm{H}, 7 \mathrm{~A}, 7 \mathrm{C})$. The hole suggests that the ovules were orthotropous, borne on a stalk, and 490-600 $\mu \mathrm{m}$ in diameter, but the length is unknown (see fig. 5). One specimen suggests that ovules were tightly packed, leaving little space for interseminal scales (fig. 6F; cf. stalks visible in fig. 5A-5C).

Two cutinized layers are visible surrounding the body of the ovule (fig. $8 A, 8 B$ ). The outer membrane is, in fact, the cuticle of the adjacent interseminal scales (line 1 in fig. 12A); it is moderately cutinized and continues apically into the interseminal scale heads surrounding the micropyle. A structure equivalent to the micropylar plate of Harris (1932), which connects the micropyle with the adjacent interseminal scales, is recognizable (fig. $7 B, 7 C$ ). The preserved portions of the interseminal scale head cuticles surround the whole micropyle as a domed collar (figs. $6 A-6 G, 7 A, 7 B$ ). The inner membrane (line 2 in fig. $12 A$; the cuticle of the outer epidermis [exotesta] of the integument) is less strongly cutinized than the cuticle of the interseminal scales and continues into the outer lining of the short micropyle. Its continuation into the inner lining of the micropyle (the lining of the micropylar canal) that extends into the cuticle of the inner epidermis (endotesta; line 3 in fig. 12A) of the integument is not preserved, but the end of the micropyle suggests that it is broken off (fig. $7 A-7 C$ ). However, it is visible in some seeds (see below). The visible inner layer of the cuticular preserved structures is therefore here interpreted to be the outer cuticle of the integument, whereas the outer layer represents the cuticle of the interseminal scales. It appears that the integument is free from the interseminal scales up to the base of the ovule (figs. 6A-6C, 6F, 7A).

Epidermal cells of the interseminal scales vary from square (about 18-21 $\mu \mathrm{m}$ across toward the interseminal scale heads) to predominantly rectangular, elongate, and in some cases very long (up to $185 \mu \mathrm{m}$ long and $17-22 \mu \mathrm{m}$ wide at the interseminal scale walls; figs. $7 C, 8 A, 8 D, 8 E$ ). The cells are thin walled, and both anticlinal and periclinal walls are typically straight, but in some distal portions of the membrane, anticlinal cell walls are slightly sinuous (fig. 6D). At the level of the ovule's apex, the interseminal scale wall cuticles continue into the interseminal scale heads, leaving a hole $(0.43 \mathrm{~mm}$ in diameter; fig. $6 \mathrm{E})$, through which the micropyle passes and projects slightly, c. 2.6$3.7 \mathrm{~mm}$ (figs. $6 F, 7 A, 7 B$ ). The epidermal anatomy of the interseminal scale heads resembles that of the interseminal scales of several Bennetticarpus T.M.Harris species (cf. Harris 1932, 1969; Hsü 1948; Pott et al. 2010a), with the difference that the anticlinal cell walls are less strongly cutinized, resembling those of the central parts of the interseminal scales in $B$. wettsteinii. Epidermal cells are small and isodiametric to gradually rectangular, 21-28 $\mu \mathrm{m}$ wide, and up to $65 \mu \mathrm{m}$ long (fig. $8 F$ ). In some specimens, sparsely distributed brachyparacytic stomata, up to $51 \mu \mathrm{m}$ long and $26 \mu \mathrm{m}$ wide, are visible (fig. 8F, 8G). The cuticle becomes delicate toward the center of the interseminal scale heads (fig. $7 B$ ).

The outer epidermis of the integument (the inner cuticular layer) consists of isodiametric cells (figs. $8 A, 8 B, 9 A, 9 B, 9 D)$, most of which are irregularly hexagonal in outline and c. $35-$ $58 \mu \mathrm{m}$ across. Cell walls are thinner than those of the interseminal scales and straight (fig. 8A, 8B). No undulation can be seen. Where the cuticle continues into the micropyle, the cells become more rectangular, elongate, and slender but are similarly thin walled and very delicate, 41-62 $\mu \mathrm{m}$ long, and 17-21 $\mu \mathrm{m}$ wide, with straight cell walls (fig. $7 B, 7 C$ ). All specimens bear regularly arranged hexagonal bodies $(15-17 \mu \mathrm{m}$ in diam.; figs. $6 E, 6 H, 7 A, 7 D, 8 D, 8 E)$, which are difficult to interpret. They have polygonal shapes and the appearance of mineral matter and might represent calcium oxalate crystals; however, their nature has not been resolved. The bodies are arranged in regular longitudinal rows and appear to be positioned between the two cuticular layers and thus between the interseminal scales and the integument.

The receptacle portion and stalks visible in figure $5 \mathrm{~A}$ are covered by numerous different monosulcate pollen grains and spores, of which two forms dominate. One of these is a small (12-18 $\mu \mathrm{m} \times 28-30 \mu \mathrm{m})$, elliptical pollen with a smooth exine (fig. 5E-5G), and the other is a larger $(27-28 \mu \mathrm{m} \times 37-39 \mu \mathrm{m})$, more spherical pollen with a striate exine (fig. $5 E-5 H$ ). The first represents a Cycadopites-type pollen (Bharadwaj and Singh 1964) similar to the pollen grains found in situ in Lunzia austriaca Krasser (Krasser 1917; Pott et al., unpublished manuscript). Clusters of pollen similar to the second type have been identified as Decussatisporites delineatus G.Leschik (Klaus 1966, 1987). Further monosulcate pollen grains ( $15 \mu \mathrm{m}$ wide, $24 \mu \mathrm{m}$ long) were also found on or in one of the ovules close to the cone surface in an area interpreted as the pollen chamber (fig. 6F, 6G). The wall structure of the pollen grains is unfortunately obscured by the overlying cuticle layers, and so further description is not possible, but their size and shape allow them to be identified with the first, laevigate type. On or in the seed shown in figure $9 B$, one monosulcate grain $(28 \mu \mathrm{m} \times 39 \mu \mathrm{m})$ with a striate exine was found (fig. 8C), which is identical to those identified as $D$. delineatus. The third most prominent grain type is large and circular, with a diameter of 38-46 $\mu \mathrm{m}$, and displays characteristic folding (fig. 5E). Owing to its size and peculiar shape, this grain type can be identified with in situ spores of Asterotheca merianii (Brongn.) Stur ex Krasser (Bharadwaj and Singh 1957; C. Pott, personal observation, 2016). Spores of this type fall within the morphological range of the fossil form genus Leschikisporis R.Potonie, with closest resemblance to Leschikisporis aduncus (G.Leschik) R.Potonié (Bharadwaj and Singh 1964).

A few dispersed seeds have also been found (fig. 9), with anatomies suggesting affiliation with $\mathrm{W}$. pramelreuthensis. The 1.62.8-mm-long and 1.3-2.2- $\mu \mathrm{m}$-wide seeds are characterized by a prominent nucellus, with a developing embryo (up to $400 \mu \mathrm{m}$ wide; e.g., fig. 9A) embedded in a wide nourishing tissue or megagametophyte that is surrounded by the integument (fig. $9 A, 9 B$, $9 D)$. In the seeds, both cuticles of the integument are recognizable, with the outer cuticle representing the exotesta (outer epidermis of the integument; line 2 in fig. 12B) and the inner cuticle representing the endotesta (inner epidermis of the integument; 

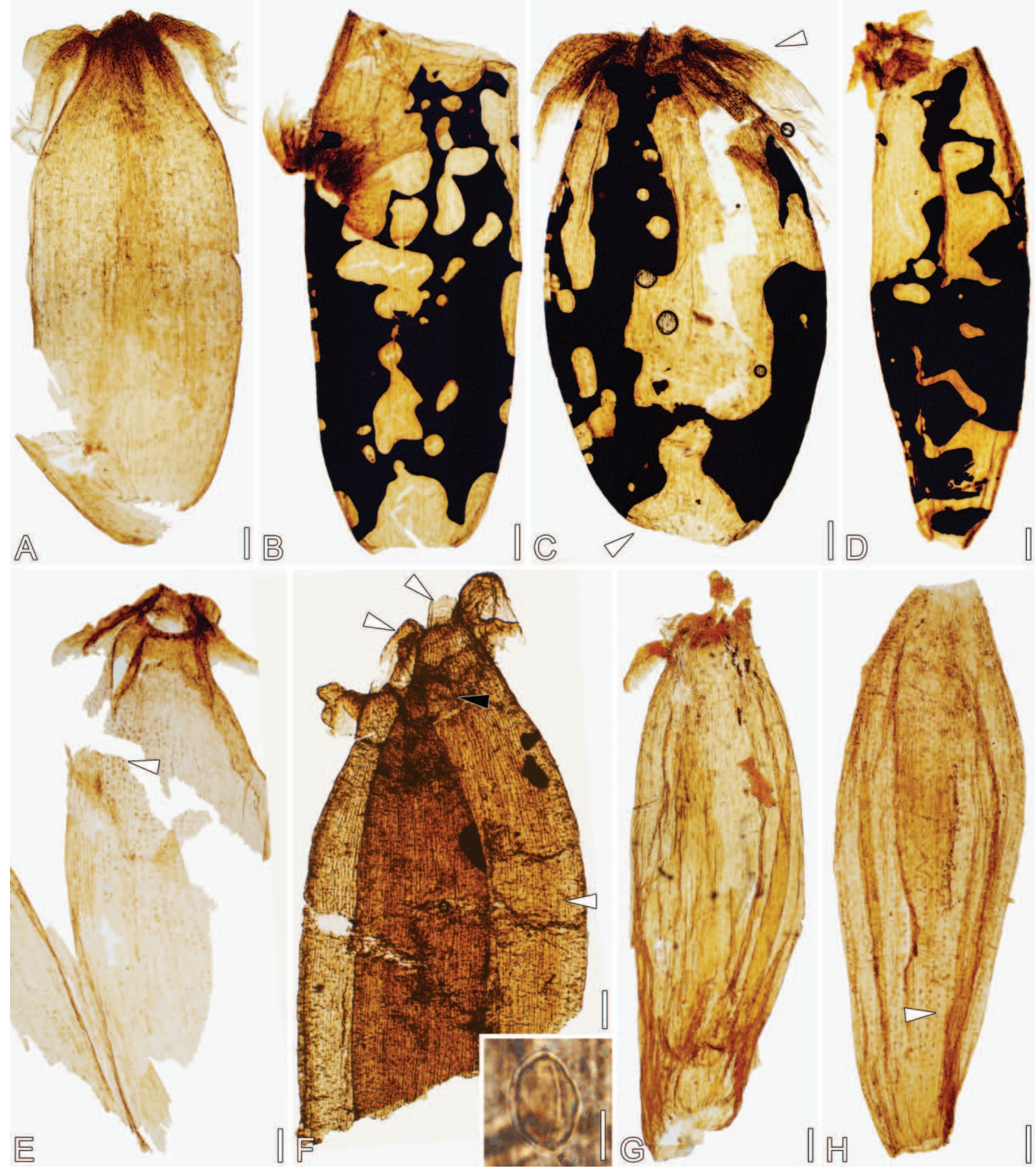

Fig. 6 Ovules of Westersheimia pramelreuthensis Krasser. Note the micropylar plates preserved in all but the last specimens. A, NHMW 1885/0500/3893/0001. B, NHMW 2006B0008/0010/0086. C, NHMW 2006B0008/0010/0087; note the proximal hole where the stalk was attached and the distal collar produced by the heads of the adjacent interseminal scales (arrowheads). D, NHMW 2006B0008/0010/0086. E, NHMW 1885/0500/4026/0012; note the (oxalate?) crystals (arrowhead). F, NHMW 1885/0500/4026/0013, two adjacent ovules; note the preserved micropyles in both, the visible nucellus cuticle (arrowheads); the black arrowhead depicts the position of the pollen grains, one of which is enlarged (inset). G, NHMW 1885/0500/3893/0002. H, NHMW 1885/0500/3893/0003; note the (oxalate?) crystals (arrowhead). Scale bars: $A-H=200 \mu \mathrm{m}$; inset $=10 \mu \mathrm{m}$. 


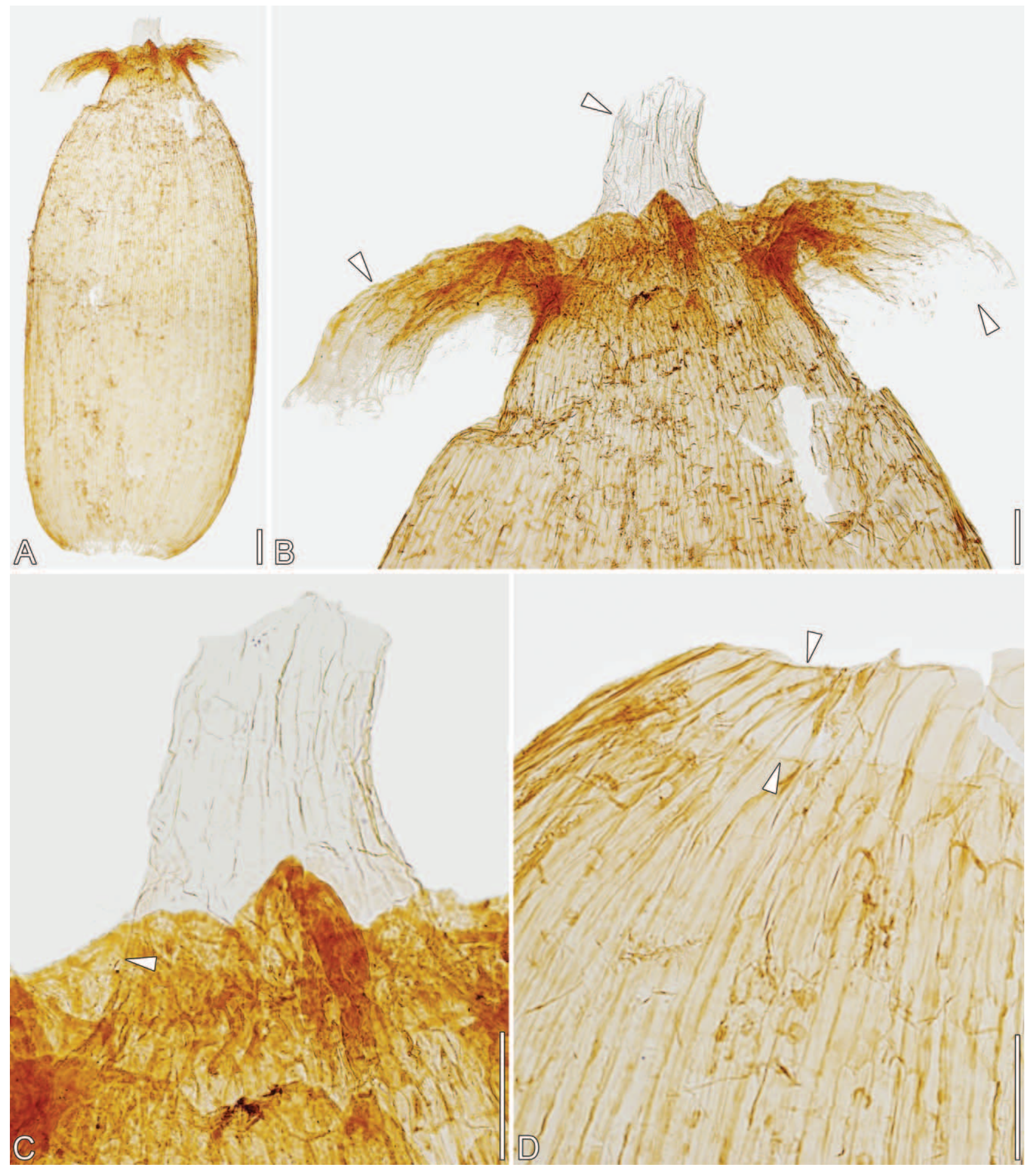

Fig. 7 Ovule of Westersheimia pramelreuthensis Krasser, NHMW 1884/0500/1202/0009. A, Overview of a complete ovule lacking the stalk; note the micropyle passing through the collar produced by portions of the heads of the adjacent interseminal scales. $B$, Detail of the apex of the ovule depicting the micropyle and the collar produced by the heads of adjacent interseminal scales (arrowheads). C, Detail of the micropyle; note the two different cuticle layers (arrowhead). $D$, Detail of the ovule base depicting the hole left by the aborted stalk (arrowheads). Scale bars: $A-C=100 \mu \mathrm{m}$; $D=10 \mu \mathrm{m}$. 

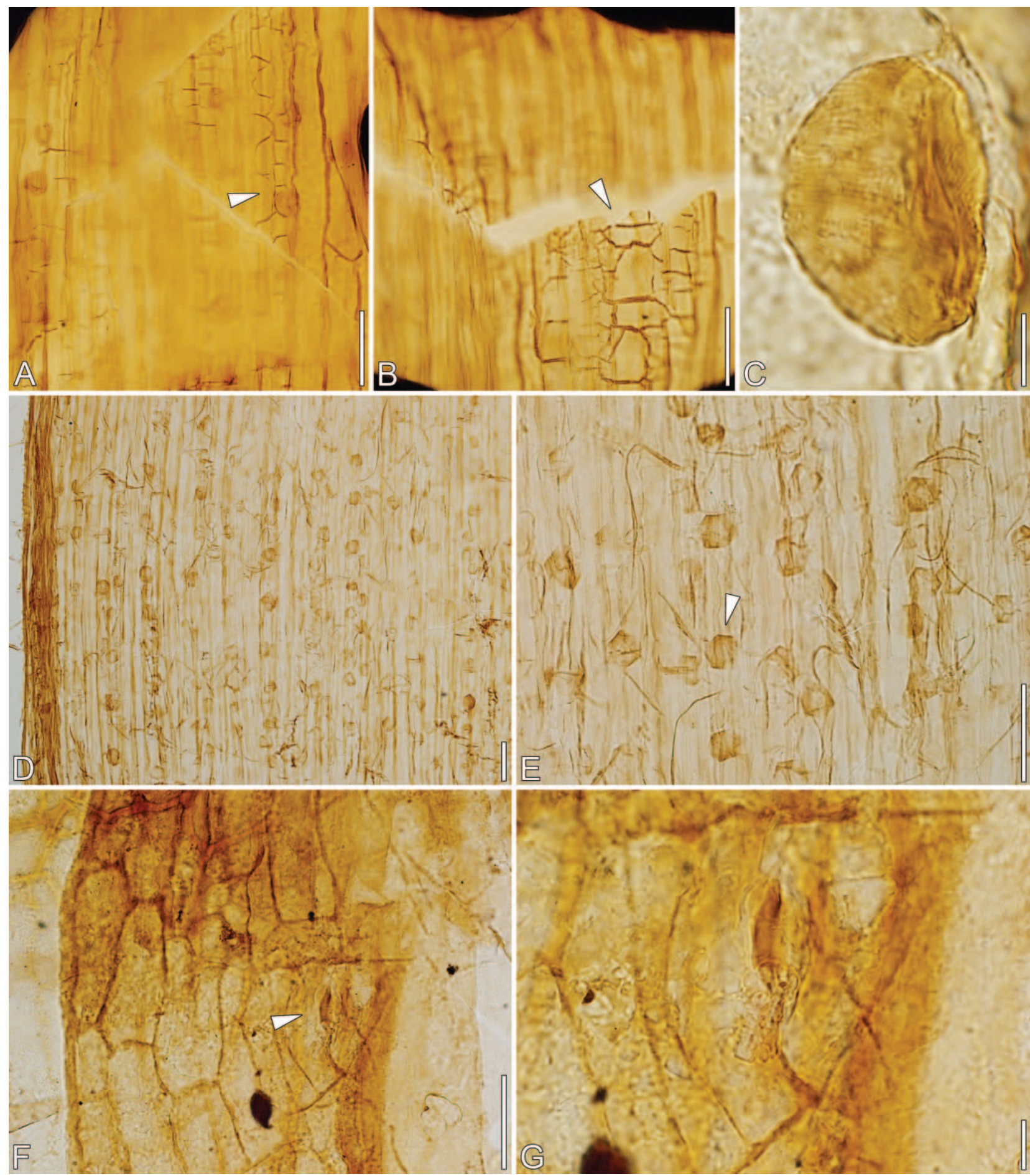

Fig. 8 Detailed views of ovules of Westersheimia pramelreuthensis Krasser. A, B, NHMW 2006B0008/010/0086, detail and cellular pattern of the inner cuticle (cuticle of the outer epidermis [exotesta] of the integument) and the outer cuticle (cuticle of the epidermis of the interseminal scale; arrowheads), lying on top of each other; note the different cell types. C, NHMW 2006B0008/0010/0089, pollen grain found in the seed in figure 9B; note the sulcus and the striate pollen wall. D, E, NHMW 1884/0500/1202/0009, cellular pattern of the inner cuticle (cuticle of the outer epidermis [exotesta] of the integument); note the regular arrangement of the (oxalate?) crystals (arrowhead). F, G, NHMW 1885/0500/3893/0001, detail of the interseminal scale head showing a brachyparacytic stoma (arrowhead in fig. $7 F$ ). Scale bars: $A, B, D-F=50 \mu \mathrm{m} ; C, G=10 \mu \mathrm{m}$. 

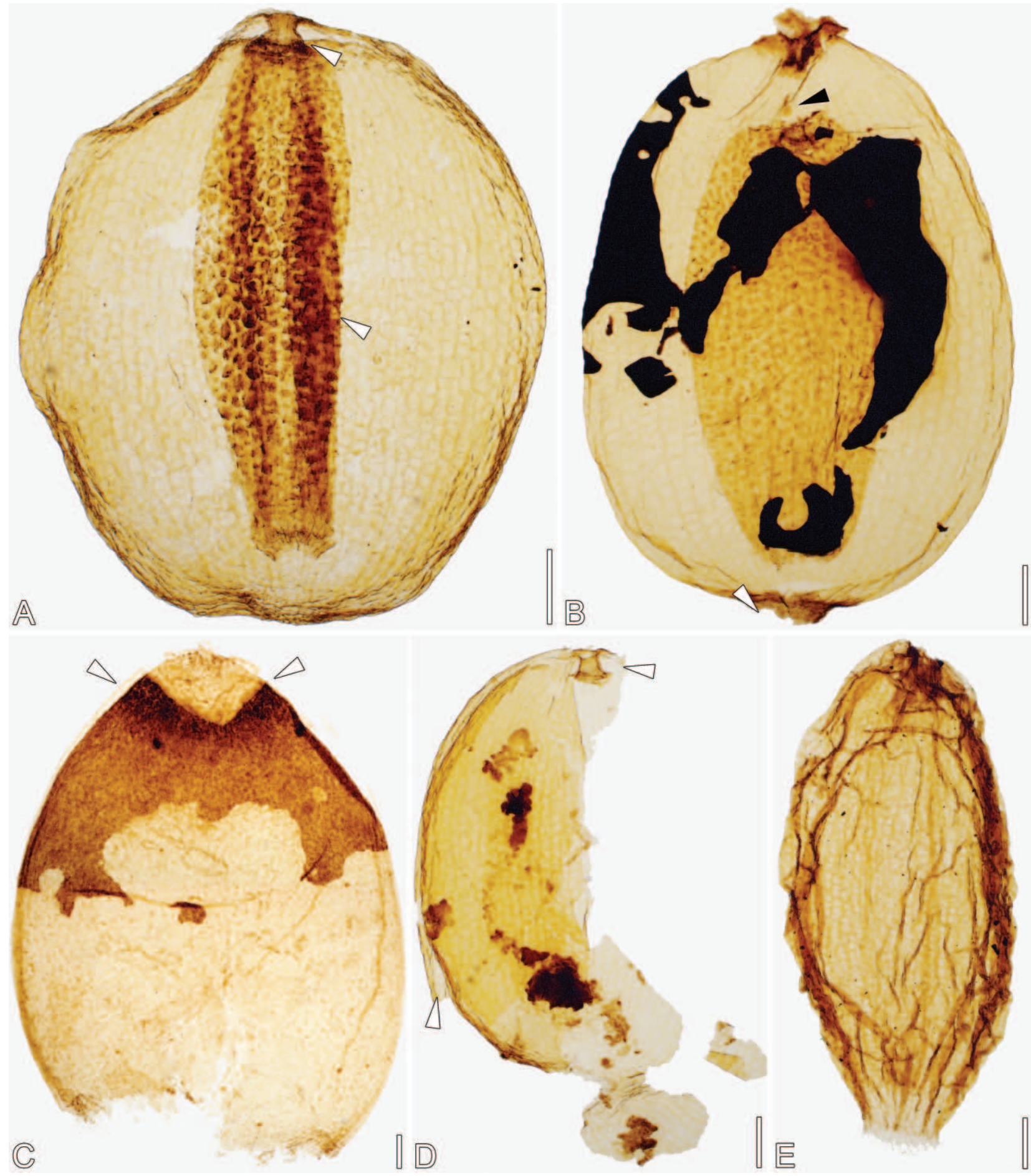

Fig. 9 Seeds of Westersheimia pramelreuthensis Krasser. A, NHMW 1885/0500/4124/00003, seed interpreted as almost mature; note the retracted micropyle and the appearing cotyledons (arrowheads). B, NHMW 2006B0008/0010/0089, seed with developing cotyledons; note the basal attachment point (white arrowhead) and the remainders of the micropyle; the black arrowhead indicates the position of the pollen grain figured in fig. 8C. C, NHWM 2006B0008/0010/0088, mature seed displaying strongly cutinized outer layer (presumably the exotesta); note the free tip of the integument (arrowheads). D, NHMW 1883/0100/5965/0003, developing seed; note the retracted micropyle and the two cuticle layers representing the exo- and endotesta of the integument (arrowheads). E, NHMW 1885/0500/4124/0006, isolated nucellus/embryo. Scale bars: $200 \mu \mathrm{m}$. 
line 3 in fig. 12B). However, in seeds of Wielandiella angustifolia (Nath.) Nath. and Bennetticarpus tylotus T.M.Harris, Harris (1932, p. 115) identified that "the epidermis of the nucellus and of the inside of the integument each possess cuticles, which have adhered to one another in fossilization." This might also be the case in the seeds presented here, and whether the inner cuticle is in fact the surface of the endotesta or of the nucellus cannot be resolved unequivocally, as they might have adhered very closely to one another (lines 3 and 4 in fig. 12B). Both the outer and the inner cuticles have a similar cellular pattern and structure as the integument of the ovules described above (fig. 9A9D). In some seeds, a rather prominent and heavily cutinized cuticle is visible (fig. 9C; removed in the lower portion, most likely by mechanical and chemical treatment during maceration), consisting of cells that Harris (1954, p. 289) identified as nucellar cells, which suggests that this is the nucellar surface (line 4 in fig. 12B) obscuring the overlying faint integumentary cells of the endotestal cuticle (line 3 in fig. 12B) from behind. Harris (1954) identified such a thick nucellar surface in bennettitalean seeds of different genera such as Williamsoniella H.H.Thomas, Williamsonia Carruth., Bennetticarpus, and Wielandiella. It is therefore not clear whether the integument grew very thick during seed development, as evidenced by anthracitic crusts or heavily coalification, which can still be seen in some of the seeds (and ovules) where the removal of coal was incomplete (figs. $6 B-6 D$, $9 B)$, or whether the nucellus produced a thick nucellar cuticle (see fig. 9C; Harris 1954).

The seeds also evidence that the micropyle was retracted during seed maturation (fig. 9A, 9D), which suggests an explanation for the absence of micropylar projections on the surface of mature bennettitalean cones commonly assigned to Williamsoniaceae, such as B. wettsteinii (fig. 10A; Pott et al. 2010a; see also below). In most seeds, the attachment point of the stalk is evident (fig. 9B, 9D). Embryos are commonly disconnected from the attachment points (fig. 9A, 9B, 9E). All seeds are interpreted to represent different stages of development, owing to the variable expansion of the nucellus or embryo and the attachment points of the stalks that suggest the seeds broke off during maceration. One seed is interpreted to be almost fully mature (fig. 9A) because the attachment point is cleanly abscised and lacks any evidence of mechanical breakage, the embryo contains two strongly cutinized cotyledons, and the nourishing tissue or megagametophyte is expanded to its full width.

Remarks. Westersheimia pramelreuthensis became renowned because the holotype specimen shows one of these organs apparently attached to a prominent stem with scars of abscised leaves, accompanied by well-preserved Pterophyllum foliage (Krasser 1917; Crane 1988). Careful reinvestigation of the original specimens of Krasser (1917), including the counterparts, revealed that the fertile organ is not organically connected to the adjacent stem. This contrasts with the main previous interpretation of the fossil (Krasser 1917, p. 549, and subsequent publications citing this interpretation; "stem of a cycadophyte with sterile foliage and fertile region"). The holotype is lacquered, hampering examination and satisfying photographic reproduction. The finish probably led earlier scholars to infer an organic connection between the stem and the delicate organ (see Kräusel 1949). However, the leaf scars visible on the stem are much larger than any scar that would have been left by the stalk of Westersheimia. Instead, these scars appear to more closely match the petioles of mature leaves of Pterophyllum filicoides (Schloth.) Zeiller (11-13 mm in diameter; Pott et al. 2007d). In addition, it would seem anomalous that such a robust stem showing scars of long abscised leaves would have produced such delicate reproductive structures based on common biological or plant anatomical understanding. Therefore, the original interpretation of this fossil warrants reassessment.
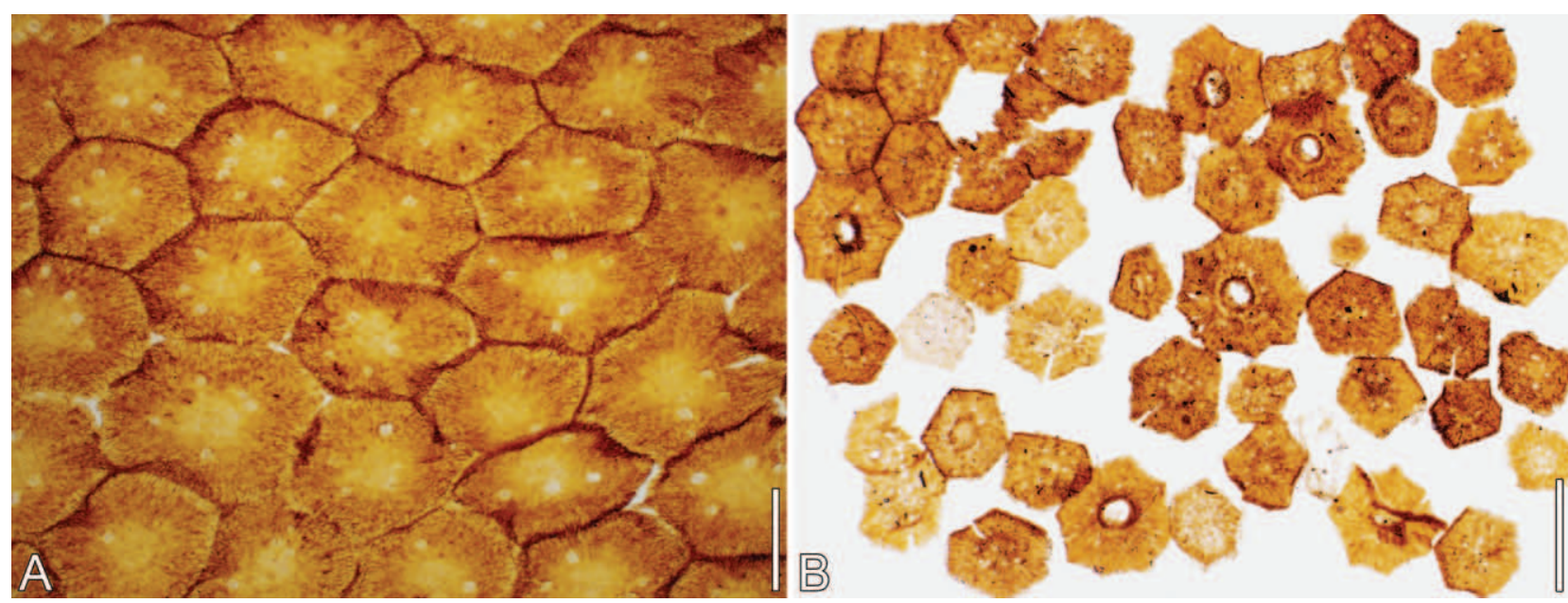

Fig. 10 Surfaces of williamsoniaceous seed cones. A, Outer surface of a mature cone of Bennetticarpus wettsteinii from the Carnian of Lunz, Austria, consisting of scale heads of only one type, GBAW 1909/002/0518/0008 (see Pott et al. 2010a); note that there is no indication of any micropyle projecting through the surface. B, Outer surface of Bennetticarpus crossospermus from the Rhaetian of Jameson Land, Greenland (see Harris 1932), with scale heads in different stages of maturation; see the main text for further explanation. The figure is a new microphotograph of slide SNMK 559, stored in the Natural History Museum of Denmark, Copenhagen. Scale bars: $500 \mu \mathrm{m}$. 
No organic connection of any Westersheimia organ to any stem is known, and therefore, the orientation of the compound structure is unknown. The Westersheimia organ is here reinterpreted from the preserved fossils as follows: the organ's secondary axes, carrying the gynoecia, were inserted in a pinnate (opposite) arrangement lateral to the central axis but then arched downward, producing pendular gynoecia and causing the down-curving of the central axis (fig. 11). This interpretation contrasts with the reconstruction proposed by Crane (1988, p. 243) and presupposes that the reproductive organ is not organically connected to the stem visible in the type specimen (as outlined above), because the orientation of the leaf scars on the stem would align it in the opposite direction. It is difficult to ascertain whether the central axis is part of the entire organ (compound organ such as ovuliferous conifer cones) or whether the individual gynoecia are all to be regarded as separate units (cones, such as simple ovuliferous cones of bennettites or cycads; see Crane 1986, 1988; Crepet and Stevenson 2010).

The mulberry-like appearance of the compressed fossils mentioned by Krasser (1917) and Langer (1943) is most likely a result of lateral distortion and compression of the gynoecia during taphonomic processes. The gynoecia were completely covered on all sides by a mantle of tightly packed interspersed ovules and interseminal scales (e.g., fig. $4 B$ ) and thus can be interpreted as cones, in contrast to the bifacial architecture of the gynoecia of Fredlindia J.M.Anderson et H.M.Anderson compound organs from the Carnian of South Africa, in which the adaxial surface of the receptacle is free of ovules and scales and which is the only organ architecturally comparable to Westersheimia. Undamaged cones of Westersheimia probably had an even surface (fig. 4J) like that visible in cones of Bennetticarpus or Vardekloeftia (see
Kräusel 1949, fig. 16; pl. 17, fig. 4; Pedersen et al. 1989; Pott et al. 2010a).

\section{Discussion}

\section{Remarks on Westersheimia and Comparisons with Similar Organs}

Westersheimia pramelreuthensis is a peculiar but intriguing bennettitalean ovuliferous organ. Hand specimens were described as early as 1916 or 1917 , but their true nature was only recognized by Kräusel (1949). The author was able to extract only two small portions of cuticle, which were useful for identifying the disarticulated ovules and interseminal scales and the dispersed seeds presented here. Portions of W. pramelreuthensis occur on 10 rock samples and have been found in a further six by maceration. Notably, W. pramelreuthensis is always closely associated with sterile foliage of Pterophyllum filicoides (Krasser 1916a, 1916b; Pott et al. 2007d).

Almost no other Triassic (Carnian-Rhaetian) material resembles Westersheimia. Reports of well-preserved pre-Jurassic ovuliferous cones and other reproductive organs of bennettites are rare (e.g., Nathorst 1902; Harris 1932; Kräusel and Schaarschmidt 1966; Ash 1968; Pedersen et al. 1989; Schweitzer and Kirchner 2003; Anderson et al. 2007; Launis et al. 2014; Pott $2014 b$; Pott et al. 2016), or the nature of the fossils remains incompletely understood (e.g., Schweitzer and Kirchner 2003; Pott et al. 2010a; Launis et al. 2014), but there are exceptions (e.g., Anderson and Anderson 2003; Pott 2014a; Pott and Axsmith 2015). The Triassic record consists mostly of disarticulated parts with little information relevant for reconstructing

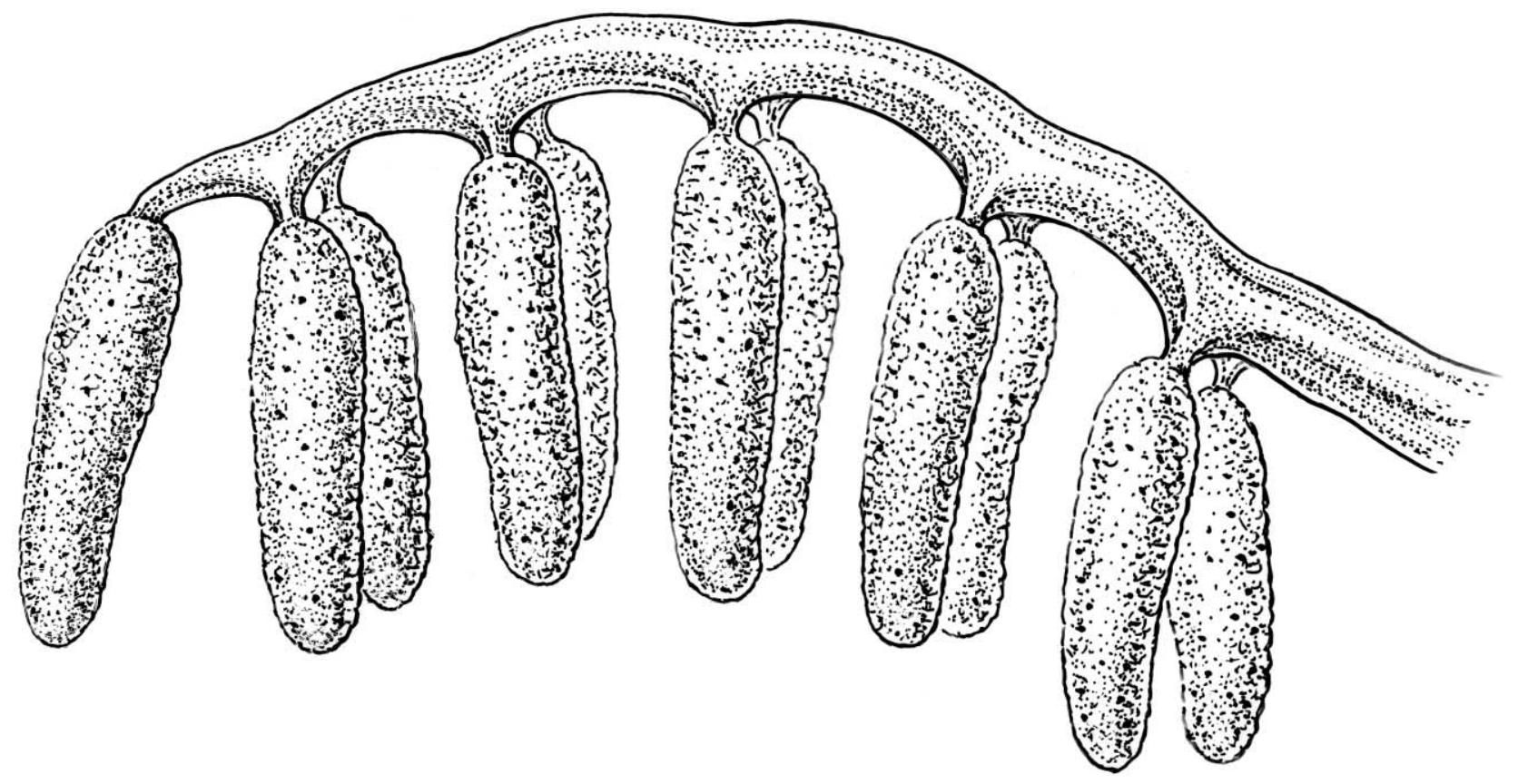

Fig. 11 Restoration of the Westersheimia pramelreuthensis Krasser ovuliferous organ. Illustration by Pollyanna von Knorring, Stockholm, Sweden. 
the organization of the reproductive organs or whole plants (Krasser 1917, 1919a, 1919b; Harris 1932; Kräusel 1948, 1949; Kräusel and Schaarschmidt 1966; Anderson and Anderson 2003; Schweitzer and Kirchner 2003; Pott et al. 2010a; Pott 2014a, 2014b; Pott and Axsmith 2015). Several additional putative bennettitalean reproductive structures have been described from the Lunz flora (Krasser 1919a; Kräusel 1948, 1949; Kräusel and Schaarschmidt 1966; Pott et al. 2010a, unpublished manuscript), but the structure and organization of some are not yet fully understood. Ovuliferous cones assigned to Wielandiella, Bennetticarpus, and Vardekloeftia from the Rhaetian of Scania, Sweden, and Jameson Land, Greenland (Harris 1932; Lundblad 1950; Pedersen et al. 1989; Pott 2014a), in contrast, preserved in excellent condition and are very useful for evaluation of this material (see below). The Rhaetian floras of Iran contain only fragmentarily preserved bennettitalean ovuliferous cones and seed cones (Schweitzer and Kirchner 2003), none of which can be compared with W. pramelreuthensis.

Due to its peculiar pinnate architecture, W. pramelreuthensis is difficult to match with other ovuliferous organs commonly assigned to Williamsoniaceae. Considering the cones (gynoecia) as individual units borne on a long shoot makes them comparable (if not homologous) with ovuliferous organs such as Wielandiella, Williamsonia, or Bennetticarpus or the ovuliferous portion of Williamsoniella in having the same internal architecture and organization (central receptacle carrying interspersed orthotropous ovuliferous and interseminal scales; Harris 1969; Watson and Sincock 1992; Pott 2014a; Pott and Axsmith 2015). These typical williamsoniaceous cones are commonly borne in branch axils and either terminate a main axis, inducing subterminate (lateral) branching (Wielandiella, Williamsonia, Bennetticarpus), or are borne in branch axils of sterile leaves (Williamsonia, Williamsoniella; Harris 1969; Pott 2014a; Pott and McLoughlin 2014), neither of which is present in the individual cones of $W$. pramelreuthensis. The mentioned cones are also commonly characterized by a subtending perianth of sterile bracts or microsporophylls (e.g., Harris 1969; Pott 2014a); cones of W. pramelreuthensis lack such a subtending structure.

If the complete pinnate structure of $W$. pramelreuthensis is considered as one unit (pinnate megasporophyll), the homologies are much more ambiguous and would have a significant effect on the position of Westersheimia within the Bennettitales, as recognized by Crepet and Stevenson (2010); when scored as pinnate, Westersheimia was placed as sister to the rest of the Bennettitales, whereas when scored unknown, relationships were unresolved. Crane (1988, p. 244) stated that it is "unclear, whether Westersheimia is a branch with several lateral branches, a branch with several megasporophylls, or a single megasporophyll with 'gynoecia' born on lateral pinnae." Crepet and Stevenson (2010, p. 233) stated that "it is obvious that further ... studies are required for definitely coding the characters of Westersheimia."

The only organ architecturally comparable to Westersheimia is the putative bennettitalean reproductive organ Fredlindia fontifructus J.M.Anderson et H.M.Anderson from the Carnian Molteno Formation of the Karoo Basin, South Africa (Anderson and Anderson 2003), which consists of a central axis bearing whorls of appendages (megasporophylls) constituting bilaterally symmetrical gynoecia incorporating orthotropous ovuliferous scales. Sterile interseminal scales are apparently ab- sent, and all scales are fertile. Each of the fleshy ovules terminates apically in a cutinized hexagonal shield and contains a long tubular micropyle that projects through the middle of this shield (Anderson and Anderson 2003). Fredlindia fontifructus and W. pramelreuthensis appear similar, but both organs are distinguished by three main characters, none of which rules out a relationship: (1) the gynoecia of $F$. fontifructus are arranged spirally or in whorls around a central axis, while in W. pramelreuthensis they are opposite (pinnate) and there is no indication that they were spirally arranged; (2) gynoecia of W. pramelreuthensis are completely covered with ovuliferous and interseminal scales (radial symmetry), while gynoecia of $F$. fontifructus are interpreted by Anderson and Anderson (2003) to be free of such scales at least on the adaxial side (bifacial symmetry); and (3) no interseminal scales are present in Fredlindia, while they are interspersed among the ovuliferous scales in Westersheimia. The latter is especially interesting regarding the relationships of Westersheimia and Fredlindia. Interseminal scales are presumably derived from sterilized ovules (and regarded as an autapomorphy of Bennettitales), so whatever group is most closely related to bennettites should not have interseminal scales but, rather, ovules that might be homologous with them, as is the case in Fredlindia.

\section{The Westersheimia Whole Plant}

Westersheimia pramelreuthensis ovuliferous organs are exclusively associated with sterile foliage identified as $P$. filicoides (Pott et al. 2007d). This can be regarded as solid evidence that both organs were produced by the same parent plant, because the fossils from Lunz appear to be parautochthonous (excellent preservation, no transport, no fluvial sorting; see Pott et al. $2008 b$ ). Whether this plant was treelike or a low-growing shrub cannot be ascertained unequivocally. The occurrence of $P$. filicoides leaves in large quantities accumulated in thick unordered layers suggests periodical shedding of leaves. Some seasonality consequently affected the plants. The pollen organ of the plant is not yet known, but the analysis of the pollen types found on the ovuliferous organs might identify Lunzia austriaca as the microsporangiate organ of Westersheimia (Pott et al., unpublished manuscript).

\section{Pollen and Pollination Strategy}

Three major types of pollen grains and spores have been found associated with the receptacle, scales, and seeds of W.pramelreuthensis. The striate pollen type (Decussatisporites delineatus) found on W. pramelreuthensis cannot unequivocally be linked with it, but if the pollen's botanical origin is interpreted as cycadophytic (cycad or bennettite; Leschik 1955; Klaus 1966), it could well be linked with Westersheimia. This is also supported by the high abundance of this pollen type on ovuliferous cones of the plant, as well as in or on its seeds. However, clusters of $D$. delineatus were also found on sterile leaves of Stachyotaxus lipoldii (Stur) Krasser by Klaus (1966; see Klaus 1987), which was earlier suggested to be a conifer (Kräusel 1949). Based on the pollen grains, Klaus (1966, p. 177) argued for a different nature of those leaves with "cryptic reminiscences of pteridosperms" (see Leschik 1955). Regarding D. delineatus as belonging to the plant producing S. lipoldii foliage (Klaus 1966) might oppose its link with W. pramelreu- 
thensis, but to link a pollen type with sterile foliage simply based on its presence on the leaf is inappropriate and highly speculative.

The large circular spore type is most likely the spore of Asterotheca merianii (Bharadwaj and Singh 1957, 1964; C. Pott, personal observation, 2016), a very common tall, treelike fern in the Lunz flora producing enormous quantities of winddispersed spores on its gigantic, probably up to 6-8-m-long fronds. These were likely to have been widely distributed and deposited, even in the smallest cavities, such as between the ovules and interseminal scales of W.pramelreuthensis, and consequently can be excluded as pollination candidates here.

The smaller, elliptic pollen type with smooth exine is similar to Cycadopites Wodehouse ex L.R.Wilson et R.M.Webster in shape and morphology. Cycadopites is regarded as a senior synonym of Monocolpopollenites H.D.Pflug et P.W.Thomson (Leschik 1955; Bharadwaj and Singh 1964). It occurs in situ in several microsporangiate organs of cycads and bennettites, among which are some from the Lunz flora. Of the organs from which this pollen type is known, pollen of Leguminanthus siliquosus (F.Leuthardt) Kräusel et F.Schaarschm. appears similar though smaller $(13 \mu \mathrm{m} \times 17 \mu \mathrm{m}$; Kräusel and Schaarschmidt 1966); its ultrastructure is consistent with its presumed bennettitalean affinity (Ward et al. 1989). Pollen of the bennettitalean L. austriaca appears similar in morphology and size $(18 \mu \mathrm{m} \times$ $27 \mu \mathrm{m}$; Krasser 1917; Kräusel and Schaarschmidt 1966; Pott, unpublished manuscript). From the size ranges of the different Cycadopites types reported from Lunz, they fit best into Cycadopites accerimus (G.Leschik) D.C.Bharadwaj et H.P.Singh (Bharadwaj and Singh 1964; = Monocolpopollenites accerrimus G.Leschik of Leschik 1955).

One of the monosulcate pollen types is the strongest candidate for affiliation with $W$. pramelreuthensis. The botanical affinity of $D$. delineatus is assumed to be with cycads or bennettites, although the pollen organ producing this pollen is not yet known. At the least, these pollen grains were dispersed in large quantities at the same time that W. pramelreuthensis was flowering. However, a few grains of the smooth, Cycadopites-like type have been found in one specimen in an area interpreted as the pollen chamber of an ovule, making this type the most likely candidate for the pollen of the Westersheimia plant; it is also the most abundant of the various grain types recorded. For this reason, it is very likely that the pollen organ of W. pramelreuthensis is L. austriaca, a cup-shaped structure resembling Weltrichia Braun. The description and interpretation of recently obtained new material of the latter with pollen grains preserved in situ is currently under revision (Pott et al., unpublished manuscript).

Irrespective of the identity of the affiliated pollen organ of W. pramelreuthensis, the deposition of different pollen grain types and spores in relatively large quantities in the smallest cavities and in certain places (collected at the base of the scales between their stalks) can be used to assess the pollination strategy of Westersheimia; such a way of deposition and concentration might indicate wind dispersal of the pollen grains and thus argue for wind pollination of the plant. Regarding the collected pollen grains at the base of the ovules or scales as targeted transfer by some arthropod pollinator is deemed unlikely, given that the pollen had to be captured by the apically situated micropyle for pollination. Therefore, wind pollination is considered more likely for W. pramelreuthensis. The organ's macroscopic anatomy supports this through the micropyles protruding from be- tween the densely arranged scales above the gynoecial surface for pollination. This pollination strategy has also been assumed for L. austriaca (Pott et al., unpublished manuscript).

The function of the crystals found in the ovules remains obscure. If they were calcium oxalate crystals, the major functions of their formation in plants would include high-capacity calcium regulation and protection against herbivory. The latter would make sense in protecting the ovuliferous organs from browsing by herbivorous tetrapods to which the plants were exposed in their natural environment (Pott and McLoughlin 2014). Williamsoniaceous bennettites seem to have experienced particularly high levels of herbivory - on both their leaves and reproductive organs - and they also had physical defenses against attacks by herbivores (Labandeira 2002; Pott et al. 2012; Pott and McLoughlin 2014; McLoughlin et al. 2015); the crystals might have been an extra form of defense against this intense herbivory.

\section{Reinterpretation of the Micropylar Plate and the Anatomy of Early Bennettitalean Seeds}

The new data on the architecture of the ovules and seeds of $W$. pramelreuthensis (fig. $12 \mathrm{~A}, 12 \mathrm{~B}$ ) contributes to the ongoing debate concerning the anatomy of bennettitalean seeds. Unitegmic seeds are characteristic of Westersheimia, conforming to the opinion that bennettitalean seeds are basically unitegmic (Seward 1917; Taylor 1981; Crane 1986; Rothwell et al. 2009). This challenges the hypothesis proposed by Friis et al. (2011) that ovules and seeds of Bennettitales can generally be regarded as bitegmic and indicative of a close relationship with Pentoxylales, Gnetales, and angiosperms (e.g., see Friis et al. 2007). Rothwell and Stockey (2002) and Stockey and Rothwell (2003) ascertained, on the basis of studies of petrified material, that the layer in Williamsonia and Cycadeoidea that was interpreted as a cupule by some authors is the sarcotesta of a single integument, not a morphologically distinct organ, and they questioned whether a cupule existed in any Bennettitales. Doyle (2008) scored Bennettitales for this character as "uncertain."

The description of Vardekloeftia from the Rhaetian of Jameson Land, East Greenland, another early bennettite that is commonly placed individually or in a clade with Westersheimia and Leguminanthus Kräusel et F.Schaarschm. as sister to the rest of the Bennettitales (Crane 1985, 1988), further stimulated the discussion (e.g., Harris 1932, 1954; Pedersen et al. 1989; Doyle 2008; Friis et al. 2011). Vardekloeftia sulcata T.M.Harris represents an ovuliferous cone with five to 20 ovoid $5.5 \times 10-\mathrm{mm}-$ large seeds (Harris 1932; Pedersen et al. 1989). Harris (1932) initially described two species (namely, Vardekloeftia conica T.M.Harris and V. sulcata) that were considered conspecific by Pedersen et al. (1989). The most conspicuous character of Vardekloeftia, in comparison with other (early) bennettites, is an additional cutinized layer surrounding the nucellus, originally termed the cupule (Harris 1932; Pedersen et al. 1989). Notably, Vardekloeftia can be regarded as a mature cone with welldeveloped seeds.

Based on this interpretation, a cellular surface has been identified surrounding the micropyle, connecting it to the adjacent interseminal scales in several other immature or maturing noncycadeoid ovuliferous cones (including some immature and mature cones of Vardekloeftia). This surface has been termed the micropylar plate by Harris (1932) and was interpreted as the 

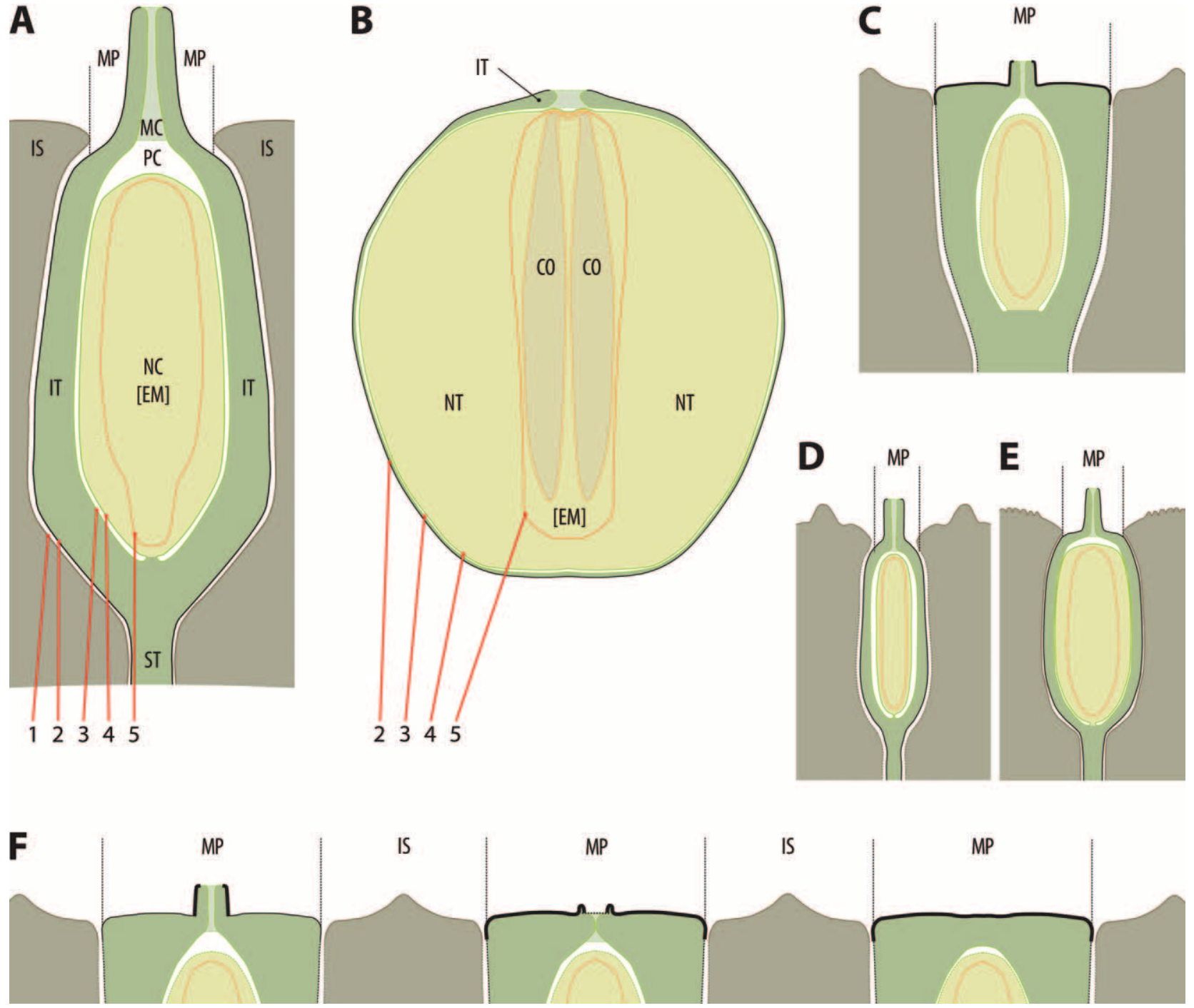

Fig. 12 Interpretative illustrations of williamsoniaceous ovules and seeds. All solid lines indicate cuticular layers. A, Ovule of Westersheimia pramelreuthensis Krasser. B, Seed of W. pramelreuthensis. C, Ovule of Bennetticarpus crossospermus (reinterpretation of Harris 1932, fig. 50C). $D$, Ovule of Wielandiella angustifolia from the Rhaetian of Jameson Land, Greenland (reinterpretation of Harris 1932, fig. 50E). E, Ovule of W. angustifolia (reinterpretation of Pott 2014a, fig. 20B). F, Illustration of the micropyle retraction process and the closing of the micropylar plate through the formation of a cuticular layer in the micropylar channel (cf. fig. $10 \mathrm{~B}$ and see the main text for further explanation). The same colors represent the same layers in each figure. co = cotyledon; em = embryo; is = interseminal scale; it = integument; $\mathrm{mc}=$ micropyle with micropylar canal; $\mathrm{mp}=$ micropylar plate; $\mathrm{nc}=$ nucellus; $\mathrm{nt}=$ nourishing tissue; $\mathrm{pc}=$ pollen chamber; $\mathrm{st}=$ stalk. Cuticular layers: $1=$ outer surface of the interseminal scale; 2 = outer surface (exotesta) of the integument; $3=$ inner surface (endotesta) of the integument; $4=$ outer surface of the nucellus; $5=$ outer surface of the embryo with the cotyledons.

apical portion of an additional tissue that enclosed the integument enveloping the nucellus, and the layer representing the integument to continue into the lining of the micropyle (Harris 1932). This anatomy led Harris (1932), Pedersen et al. (1989), and other authors to develop the hypothesis that ovuliferous and interseminal scales in bennettitaleans commonly assigned to Williamsoniaceae are homologous (cf. Pedersen et al. 1989; Friis et al. 2011). This was inferred from the similarity in cellular composition, pattern, and structure between the micropylar plate and the heads of the interseminal scales (Harris 1932; Pedersen et al. 1989); an additional argument was the micropyle projecting through "a clean-cut hole in the middle of the micropylar plate" (Harris 1932, p. 105). It has to be noted, however, that it is rather unlikely that a micropyle would leave such a clean-cut hole, as it would always be continuous with the adjacent tissue. Similar micropylar plates were recognized by Harris (1932) and Hsü (1948) in various Bennetticarpus species and purportedly also occur in material from the Jurassic of Yorkshire-e.g., in Williamsonia himas T.M.Harris or Williamsonia leckenbyi Nath. (Harris 1969; Friis et al. 2011).

The homology between interseminal and ovuliferous scales has been emphasized (e.g., Harris 1932; see Friis et al. 2011); the interseminal scales are thus seen as sterile cupules in which "the nucellus and the integument failed to develop" (Pedersen 
et al. 1989, p. 21). Harris (1932) and Pedersen et al. (1989) argued that the tissue separating the integument from adjacent interseminal scales is a separately developing outer layer (cupule or seed envelope) of Vardekloeftia and Bennetticarpus ovules and seeds. This outer layer, represented by the micropylar plate, consequently corresponds to or develops into an outer seed coat in mature seeds of Vardekloeftia (Pedersen et al. 1989), leading to the mentioned interpretation of the anatomy of mature seeds in these bennettitaleans commonly assigned to Williamsoniaceae as bitegmic.

However, the interpretation outlined above lacks consistency: although all cupules are not homologous, a cupule originates from either the receptacle and axis tissue or the scale leaves and is consequently never produced from tissue of the ovule. Thus, if these structures are interpreted to be derived from sterile ovules, then they should not be referred to as cupules. Interpreting it as a seed envelope links it to a similar structure seen in two of the three surviving members of Gnetales (namely, Ephedra L. and Welwitschia Hook.f.; Martens 1971; Bornman et al. 1972; Yang 2001; Doyle 2008; Friis et al. 2014), where an outer and an inner envelope are recognizable surrounding the nucellus. Ontogenetic studies proposed that the inner envelope is the actual integument of the Ephedra ovule (e.g., Martens 1971; Yang 2001). The outer envelope, termed a cupule by Yang (2001), is not homologous with an integument, because integuments are produced from the chalaza (but it could be homologous with the outer layer in Vardekloeftia). Friis et al. (2007) later interpreted the seed envelope/cupule in Bennettitales as bracts. It appears that particular attention to consistent terminology is of high importance, especially with regard to the use of the term cupule (e.g., see supplemental section 3 of Doyle 2012 for a detailed discussion of the "Homologies of ovulate structures in Bennettitales and Pentoxylon").

Furthermore, generalizations of seed structure in Bennettitales that extrapolate from a few examples (fundamentally only one example; e.g., Friis et al. 2007, 2011; Rothwell et al. 2009; Crepet and Stevenson 2010) may be misleading. The suggestion that all seeds in Bennettitales have equivalent architecture may not be correct, and examination of available original material might be warranted. For example, many reproductive organs interpreted by Friis et al. (2011) to show a micropylar plate as the apical portion of the seed envelope, based on illustrations alone, are misinterpreted or lack the proposed structure. The reexamination of Harris' (1932) original slides made from Bennetticarpus crossospermus T.M.Harris conducted for this study, for example, raises further doubts about the existence of a micropylar plate. All shields in the microscopic slide of Harris represent prominent scale heads, some of which have an embossed circular structure (bulge) in the center (fig. 10B; see also Harris 1926). Several of these scale heads represent different stages of development (fig. 10B). Some show a cutinized head with the circular bulge and a hole; in others, the central hole is covered (closed) by a thin cuticle. In some heads, this cuticle is of almost entirely the same thickness and structure as the surrounding cuticle, and the central ringlike bulge is greatly reduced. This fact was originally recognized by Harris (1926) but had been obscured in the later schematic illustrations of Harris (1932; the author provided only schematic, line-drawn, blank hexagons with a circle in the middle), confusing contemporary and later scholars. As B. crossospermus is a mature seed cone, these structures are more likely to be interpreted as the apical surface of the ovules in different stages of maturation that became progressively cutinized, with the micropyle in the process of retracting or being aborted in the center and its projection hole closing (fig. 12F). Consequently, the micropylar plate is not the apical surface of an additional layer surrounding the integument but the apical surface of the integument itself (the shoulder of the ovule; see fig. $12 \mathrm{~A}, 12 \mathrm{C}-12 \mathrm{E}$ for illustration). Supportive information comes from the ovules of $F$. fontifructus, which also show ovuliferous scales with a long tubular micropyle that projects beyond the apical surface (the micropylar plate or shoulder of the ovule) in receptive ovules but retracts in those assumed to have been pollinated (Anderson and Anderson 2003). This may also increase the plausibility of the bennettitalean nature of Fredlindia.

This interpretation also suggests an explanation, for example, for seed cone surfaces where no micropyles are visible at all, such as Bennetticarpus wettsteinii (Pott et al. 2010a). Pott et al. $(2010 a)$ explained the absence of micropyles as a swelling of the interseminal scales during seed maturation into a fleshy layer that could attract potential seed dispersers; during this process, the micropylar openings were closed. The material analyzed here indicates that the ovuliferous scales can also be involved in this process. The seeds show different retraction stages of micropyles, concomitant with an increased fleshiness of the ovules themselves. In the seed interpreted to be most mature (ripe), the micropyle is completely retracted (fig. 9A).

The interpretation presented here does not reject the assumed homology of ovuliferous and interseminal scales. The difference is that interseminal scales are not cupules, where the "integument and the nucellus failed to develop" (Pedersen et al. 1989 , p. 21), but remnants of the integument that failed to differentiate from the nucellus or in which the nucellus failed to develop (see Pedersen et al. 1989; compare with ovules of $F$. fontifructus).

Moreover, W. leckenbyi, W. himas, and Bennetticarpus tylosus T.M.Harris (Harris 1932, pl. 15, fig. 6; Harris 1969, figs. $57 \mathrm{~F}, 60 \mathrm{~K}$ ) show no layer that can be interpreted as the micropylar plate in Harris' sense. What earlier authors (e.g., Friis et al. 2011) interpreted as the micropylar plate in Harris' sense is simply the outer cuticle of the micropyle (and thus the projection of the apical surface of the ovule) distorted through compression during taphonomy in some specimens (Harris 1969, p. 133). The same can be observed in ovuliferous cones of Wielandiella angustifolia from the same deposits as B. crossospermus (Pott 2014a; also termed micropylar plate in that article) and is also the case in ovules and seeds of various Bennetticarpus species described from the Rhaetian of Liling, Hunan, China, by Hsü (1948), which show a remarkable similarity to the Westersheimia specimens from Lunz in architecture, structure, and sizes (what Hsü [1948] regarded as the micropylar plate is again the shoulder of the ovules). The term micropylar plate itself might still be useful if it is not regarded as the apical surface of an additional layer between the integument and adjacent interseminal scales but is simply used to denote the apical surface of the ovule (and thus the integument; fig. 12D-12F), which is less developed in Westersheimia than in some of the taxa discussed here (see fig. 12).

Ovules of Wielandiella (Pott 2014a) and Westersheimia as described here are definitely unitegmic. The same is true for many Triassic and Jurassic Bennetticarpus and Williamsonia species and the ovules of Williamsoniella (Harris 1969). The sit- 
uation in mature seeds of Vardekloeftia is unclear; an alternative explanation could be that the integument is split entirely or apically during seed maturation into two layers that originate from the exo- and the endotesta to form a multilayered seed coat. Unfortunately, the material is inaccessible and not available for further examination. In some phylogenetic analyses, Vardekloeftia is placed at the base of the Bennettitales (e.g., Crane 1985, 1986; not considered by Crepet and Stevenson 2010) and regarded as an early member of the group (Pedersen et al. 1989), which might argue for a multilayered seed coat as the ancestral state in Bennettitales (Crane 1985; see also Stockey and Rothwell 2003). Vardekloeftia has been tentatively discussed by Pott $(2014 a)$ as the mature seed cone of Wielandiella. Stimulated by the interpretations of Harris (1932), Pedersen et al. (1989), and Friis et al. (2011), Pott (2014a) misinterpreted Wielandiella as having two morphologically distinct layers around the ovules (Pott 2014a, see especially figs. 13A, 13B, $20 B$ but compare with fig. $12 E$ in this article). This view must now be corrected based on critical reevaluation of the Wielandiella specimens stimulated by the results and reinvestigations in the course of this study. An updated graphical interpretation of the ovules of W. angustifolia is provided in figure $12 \mathrm{D}, 12 \mathrm{E}$.

The question of whether bennettitalean seeds are uni- or bitegmic is rich in discussions and options (e.g., Stockey and Rothwell 2003; Friis et al. 2007, 2011; Doyle 2008, 2012; Rothwell et al. 2009; Crepet and Stevenson 2010). The debate is complicated by the different use of morphological terms and concepts, but there are elaborate studies that evaluated the homologies of these structures (e.g., Doyle 2008, 2012). Here, I supply updated information on Westersheimia and Wielandiella (Pott 2014a), available for use in future phylogenetic analyses. Providing new and updated information on the poorly understood but often cited members of early Bennettitales from critical but long-neglected Late Triassic floras (e.g., Pott et al. 2010; Pott 2014a, 2016; Pott, work in progress) is important and may advance progress in our understanding of the Bennettitales. In the past decades, not only have several significant members of early Bennettitales been described, but the available knowledge of Bennettitales on, for example, whole plants and overall plant architecture, habit, reproductive morphology, and reproductive strategies (e.g., see Pott 2014a; Pott and McLoughlin 2014), among others, has also increased considerably. These data, in combination with the suggestion presented here that seeds of several bennettitalean taxa were unitegmic rather than bitegmic, provide strong potential to help resolve relationships within Bennettitales and of Bennettitales with other major seed plant groups.

\section{Conclusions}

Hand specimens and disarticulated or isolated ovules and interseminal scales, as well as dispersed seeds of the peculiar ovuliferous organ Westersheimia pramelreuthensis from the Carnian of Lunz, Austria, provide vital information on the architecture and structure of ovules and seeds of early Bennettitales. The different cuticle layers are interpreted to represent the epidermis of the interseminal scales and the outer epidermis (exotesta) of the integument. The inner epidermis (endotesta) of the integument is inferred from cuticle remains visible in the micropylar region. Based on the new results and a reevaluation of ovuliferous cones of Williamsoniaceae from the Rhaetian of Jameson Land (Greenland) and Scania (Sweden) and the Bajocian of Yorkshire (United Kingdom), the interpretation of the so-called micropylar plate, a term established by Harris (1932) for a cuticle area of what the author interpreted as the apical surface of an additional layer surrounding the integument, later termed a cupule (Harris 1932; Pedersen et al. 1989) and seed envelope (Friis et al. 2007, 2011), is challenged. Instead, the micropylar plate is more likely to represent the apical surface (shoulder) of the ovule and thus the integument (see fig. 12 for illustration).

This implies that bennettitalean seeds cannot be regarded as fundamentally bitegmic structures in general (Pedersen et al. 1989; Friis et al. 2011, p. 127). In contrast, bennettitalean seeds are unitegmic, with the possible exception of Vardekloeftia, in which the question of whether the outer layer is a morphologically distinct organ or a differentiated layer of the integument is potentially resolvable. In case it is a separate organ, the question of whether it is part of the seed, an integument, and so on depends on the definitions of these terms. In conclusion, it is realized from this survey that a careful study of the fossil material across Bennettitales is needed and the examination and consideration of original material is required, because, as documented, schematic illustrations tend to be biased or not show sufficient details; in addition, particular attention to consistent terminology is of high importance.

\section{Acknowledgments}

This study would not have been possible without the permission of the Museum of Natural History (NHMW), Vienna, and the Geological Survey of Austria (GBAW), Vienna, to consume some of the fossils for bulk maceration. Staff at the Palaeontological Department of the NHMW, especially Andreas Kroh, and at GBAW, especially Irene Zorn, are thanked for permissions and all support provided. The samples were dissolved and macerated at the Palaeobotany Research Group of the University of Münster during my $\mathrm{PhD}$ under supervision of Hans Kerp and Michael Krings. Both are thanked for all support and assistance. Friðgeir Grímsson and Reinhard Zetter, University of Vienna, helped with the identification of the pollen grains. Guido Grimm, University of Vienna, and Steve McLoughlin, Swedish Museum of Natural History, Stockholm, are thanked for critical considerations about some facts discussed here. Financial support from the Swedish Research Council (Vetenskapsrådet), under grant 621-2012-4375, is acknowledged. I thank James A. Doyle, University of California, Davis, and an anonymous reviewer for very useful comments and suggestions that helped to improve the manuscript.

\section{Literature Cited}

Anderson JM, HM Anderson 2003 Heyday of the gymnosperms: systematics and biodiversity of the late Triassic Molteno fructifications. SANBI, Pretoria, South Africa.
Anderson JM, HM Anderson, CJ Cleal 2007 Brief history of the gymnosperms: classification, biodiversity, phytogeography and ecology. SANBI, Pretoria, South Africa. 
Arber EAN, J Parker 1907 On the origin of angiosperms. J Linn Soc Bot 38:29-80.

Ash SR 1968 A new species of Williamsonia from the Upper Triassic Chinle Formation of New Mexico. J Linn Soc Bot 61:113-120.

Bharadwaj DC, HP Singh 1957 Asterotheca meriani (Brongn.) Stur and its spores from the Upper Triassic of Lunz (Austria). Palaeobotanist 5:51-55.

1964 An Upper Triassic miospore assemblage from the coals of Lunz, Austria. Palaeobotanist 12:28-44.

Bornman CH, JA Elsworthy, V Butler, CEJ Botha 1972 Welwitschia mirabilis: observations on general habit, seed, seedling, and leaf characteristics. Madoqua Ser II 1:53-66.

Crane PR 1985 Phylogenetic analysis of seed plants and the origin of angiosperms. Ann Mo Bot Gard 72:716-793.

1986 The morphology and relationships of Bennettitales. Pages 163-175 in BA Thomas, ed. Systematic and taxonomic approaches in palaeobotany. Oxford University Press, Oxford.

1988 Major clades and relationships in the "higher" gymnosperms. Pages 218-272 in CB Beck, ed. The origin and evolution of gymnosperms. Columbia University Press, New York.

Crepet WL, DM Stevenson 2010 The Bennettitales (Cycadeoidales): a preliminary perspective of this arguably enigmatic group. Pages 215-244 in CT Gee, ed. Plants in Mesozoic time: morphological innovations, phylogeny, ecosystems. Indiana University Press, Bloomington.

Doyle JA 2006 Seed ferns and the origin of angiosperms. J Torrey Bot Soc 133:169-209.

2008 Integrating molecular phylogenetic and paleobotanical evidence on origin of the flower. Int J Plant Sci 169:816-843.

2012 Molecular and fossil evidence on the origin of angiosperms. Annu Rev Earth Planet Sci 40:301-326.

Doyle JA, MJ Donoghue 1986 Seed plant phylogeny and the origin of angiosperms: an experimental cladistic approach. Bot Rev 52: 321-431.

Dunay RF, MJ Fisher 1978 The Carnian palynofloral succession in the Northern Calcareous Alps, Lunz-am-See, Austria. Pollen Spores 20:177-187.

Friis EM, PR Crane, KR Pedersen, S Bengtson, PCJ Donoghue, GW Grimm, M Stampanoni 2007 Phase-contrast X-ray microphotography links Cretaceous seeds with Gnetales and Bennettitales. Nature 450:549-552.

Friis EM, KR Pedersen, PR Crane 2009 Early Cretaceous mesofossils from Portugal and eastern North America related to the BennettitalesErdtmanithecales-Gnetales group. Am J Bot 96:252-283.

2011 Early flowers and angiosperm evolution. Cambridge University Press, Cambridge.

2014 Welwitschioid diversity in the Early Cretaceous: evidence from fossil seeds with pollen from Portugal and eastern North America. Grana 53:175-196.

Harris TM 1926 The Rhaetic flora of Scoresby Sound, East Greenland. Medd Grønl 48:45-148.

1932 The fossil flora of Scoresby Sound, East Greenland.

III. Caytoniales and Bennettitales. Medd Grønl 85:1-133.

1954 Mesozoic seed cuticles. Sv Bot Tidskr 48:281-291.

1969 The Yorkshire Jurassic flora. III. Bennettitales. Trustees of the British Museum, London.

Hilton J, RM Bateman 2006 Pteridosperms are the backbone of seedplant phylogeny. J Torrey Bot Soc 133:119-168.

Hornung T, R Brandner 2005 Biochronostratigraphy of the Reingraben Turnover (Hallstatt Facies Belt): local black shale events controlled by regional tectonics, climatic change and plate tectonics. Facies 51:460-479.

Hsü J 1948 On some fragments of bennettitalean "flowers" from the Liling Coal Series of east Hunan. Natl Peking Univ 50th Anniv Pap Geol Ser:57-68.
Kerp H 1990 The study of fossil gymnosperms by means of cuticular analysis. Palaios 5:548-569.

Klaus W 1966 Zwei Pflanzenreste der alpinen Trias mit ihren Sporen (Lueckisporites und Decussatisporites). Verh Geol Bundesanst Wien: 172-177.

— 1987 Einführung in die Paläobotanik. Deuticke, Wien, Austria.

Krasser F 1916a Studien über die fertile Region der Cycadophyten aus den Lunzer Schichten: Mikrosporophylle und männliche Zapfen. Österr Bot Z 66:285-286.

$1916 b$ Studien über die fertile Region der Cycadophyten aus den Lunzer Schichten: Mikrosporophylle und männliche Zapfen. Anz Akad Wissensch Wien Mat-Naturw K1 27:335-337.

1917 Studien über die fertile Region der Cycadophyten aus den Lunzer Schichten: Mikrosporophylle und männliche Zapfen. Denkschr Kaiserl Akad Wissensch Wien Mat-Naturw Kl 94:489-553.

_ 1919a Studien über die fertile region der Cycadophyten aus den Lunzer Schichten: Makrosporophylle. Denkschr Kaiserl Akad Wissensch Wien Mat-Naturw Kl 97:1-32.

- 1919b Ein neuer Typus einer männlichen WilliamsoniaBecherblüte aus der alpinen Trias. Sitzungsber Kaiserl Akad Wissenschaf Wien 128:525-534.

Kräusel R 1948 Sturiella langeri nov. gen., nov. sp., eine Bennettitee aus der Trias von Lunz (Nieder-Österreich). Senckenbergiana 29: 141-149.

1949 Koniferen und andere Gymnospermen aus der Trias von Lunz, Nieder-Österreich. Palaeontographica B 89:35-82.

Kräusel R, F Schaarschmidt 1966 Die Keuperflora von Neuewelt bei Basel. IV. Pterophyllen und Taeniopteriden. Schweiz Palaeontol Abh 84:3-44.

Kustatscher E, C Pott, JHA Van Konijnenburg-van Cittert 2011 A contribution to the knowledge of the Triassic fern genus Symopteris. Rev Palaeobot Palynol 165:41-60.

Labandeira CC 2002 The history of associations between plants and animals. Pages 26-261 in CM Herrera, O Pellmyr, eds. Plant-animal interactions: an evolutionary approach. Blackwell, London.

Langer J 1943 Über einige Stücke aus der Keuperflora von Lunz (Niederdonau). Ber Reichsamts Bodenforsch:52-58.

Launis A, C Pott, A Mørk 2014 A glimpse into the Carnian: Late Triassic plant fossils from Hopen, Svalbard. Norw Pet Dir Bull 11:35-42.

Leschik G 1955 Die Keuperflora von Neuewelt bei Basel. II. Die Isound Mikrosporen. Schweiz Palaeontol Abh 72:1-70.

Lundblad AB 1950 Studies in the Rhaeto-Liassic floras of Sweden. I. Pteridophyta, Pteridospermae and Cycadophyta from the mining district of NW Scania. Kungl Sv Vetensk Handl 1:1-82.

Martens P 1971 Les gnétophytes. In Encyclopedia of plant anatomy. Vol 12, pt 2. Borntraeger, Stuttgart, Germany.

McLoughlin S, SK Martin, R Beattie 2015 The record of Australian Jurassic plant-arthropod interactions. Gondwana Res 27:940-959.

McNeill J, FR Barrie, WR Buck, V Demoulin, W Greuter, DL Hawksworth, PS Herendeen, et al 2012 International code of nomenclature for algae, fungi, and plants (Melbourne code). Regnum Vegetabile 154. Koeltz Scientific, Koenigstein, Germany.

Nathorst AG 1902 Beiträge zur Kenntnis einiger mesozoischer Cycadophyten. Kungl Sv Vetensk Handl 36:1-28.

Pedersen KR, PR Crane, EM Friis 1989 The morphology and phylogenetic significance of Vardekloeftia Harris (Bennettitales). Rev Palaeobot Palynol 60:7-24.

Pott C 2007 Cuticular analysis of gymnosperm foliage from the Carnian (Upper Triassic) of Lunz, Lower Austria. PhD diss. Faculty of Geosciences, University of Münster, Münster.

_ 2014a A revision of Wielandiella angustifolia - a shrub-sized bennettite from the Rhaetian-Hettangian of Scania, Sweden, and Jameson Land, Greenland. Int J Plant Sci 175:467-499.

$2014 b$ The Triassic flora of Svalbard. Acta Palaeontol Polon 59:709-740 
Pott C, BJ Axsmith 2015 Williamsonia carolinensis sp. nov. and associated Eoginkgoites foliage from the Upper Triassic Pekin Formation: implications for early evolution in Williamsoniaceae (Bennettitales). Int J Plant Sci 176:174-185.

Pott C, H Kerp 2008 Mikroskopische Untersuchungsmethoden an fossilen Pflanzenabdrücken. Präparator 54:38-49.

Pott C, H Kerp, M Krings 2007a Morphology and epidermal anatomy of Nilssonia (cycadalean foliage) from the Upper Triassic of Lunz (Lower Austria). Rev Palaeobot Palynol 143:197-217.

2008a Sphenophytes from the Carnian (Upper Triassic) of Lunz am See (Lower Austria). Jahrb Geol Bundesanst Wien 148:183-199.

Pott C, M Krings 2010 Gymnosperm foliage from the Upper Triassic of Lunz, Lower Austria: an annotated check list and identification key. Geo.Alp 7:19-38.

Pott C, M Krings, H Kerp 2007b A surface microrelief on the leaves of Glossophyllum florinii (?Ginkgoales) from the Upper Triassic of Lunz, Austria. Bot J Linn Soc 153:87-95.

2007c First record of Nilssoniopteris (Gymnospermophyta, Bennettitales) from the Carnian (Upper Triassic) of Lunz, Lower Austria. Palaeontology 50:1299-1318.

$2008 b$ The Carnian (Late Triassic) flora from Lunz in Lower Austria: palaeoecological considerations. Palaeoworld 17:172-182.

Pott C, M Krings, H Kerp, EM Friis 2010a Reconstruction of a bennettitalean flower from the Carnian (Upper Triassic) of Lunz, Lower Austria. Rev Palaeobot Palynol 159:94-111.

Pott C, S McLoughlin 2009 Bennettitalean foliage from the RhaetianBajocian (latest Triassic-Middle Jurassic) floras of Scania, southern Sweden. Rev Palaeobot Palynol 158:117-166.

2014 Divaricate growth habit in Williamsoniaceae: unravelling the ecology of a key Mesozoic plant group. Palaeobiodivers Palaeoenviron 94:307-325.

Pott C, S McLoughlin, A Lindström 2010b Late Palaeozoic foliage from China displays affinities to Cycadales rather than to Bennettitales necessitating a re-evaluation of the Palaeozoic Pterophyllum species. Acta Palaeontol Polon 55:157-168.

Pott C, S McLoughlin, S Wu, EM Friis 2012 Trichomes on the leaves of Anomozamites villosus sp. nov. (Bennettitales) from the Daohugou beds (Middle Jurassic), Inner Mongolia, China: mechan- ical defence against herbivorous arthropods. Rev Palaeobot Palynol 169:49-60.

Pott C, S Schmeißner, G Dütsch, JHA Van Konijnenburg-van Cittert 2016 Bennettitales in the Rhaetian flora of Wüstenwelsberg, Bavaria, Germany. Rev Palaeobot Palynol 232:98-118.

Pott C, JHA Van Konijnenburg-van Cittert, H Kerp, M Krings 2007d Revision of the Pterophyllum species (Cycadophytina: Bennettitales) in the Carnian (Late Triassic) flora from Lunz, Lower Austria. Rev Palaeobot Palynol 147:3-27.

Roghi G 2004 Palynological investigations in the Carnian of the Cave del Predil area (Julian Alps, NE Italy). Rev Palaeobot Palynol 132:1-35.

Rothwell GW, WL Crepet, RA Stockey 2009 Is the anthophyte hypothesis alive and well? new evidence from the reproductive structures of Bennettitales. Am J Bot 96:296-322.

Rothwell GW, RA Stockey 2002 Anatomically preserved Cycadeoidea (Cycadeoidaceae), with a re-evaluation of systematic characters for the seed cones of Bennettitales. Am J Bot 89:1447-1458.

Schweitzer H-J, M Kirchner 2003 Die rhäto-jurassischen Floren des Iran und Afghanistans. 13. Cycadophyta III. Bennettitales. Palaeontographica B 264:1-166.

Seward AC 1917 Fossil plants-a textbook for students of botany and geology. Vol 3. Cambridge University Press, Cambridge.

Stockey RA, GW Rothwell 2003 Anatomically preserved Williamsonia (Williamsoniaceae): evidence for bennettitalean reproduction in the Late Cretaceous of western North America. Int J Plant Sci 164:251-262.

Taylor TN 1981 Palaeobotany: an introduction to fossil plant biology. McGraw Hill, New York.

Taylor TN, EL Taylor, M Krings 2009 Paleobotany: the biology and evolution of fossil plants. Academic Press, Burlington, MA.

Ward JV, JA Doyle, CL Hotton 1989 Probable granular magnoliid angiosperm pollen from the Early Cretaceous. Pollen Spores 33:101-120.

Watson J, CA Sincock 1992 Bennettitales of the English Wealden. Monogr Palaeont Soc Lond 145:1-228.

Yang Y 2001 Ontogeny and metamorphic patterns of female reproductive organs of Ephedra sinica Stapf (Ephedraceae). Acta Bot Sin 43:1011-1017. 